Western University Scholarship@Western

1971

\title{
Barriers to Entry as a Measure of a Firm's Monopoly Power
}

John P. Palmer

Follow this and additional works at: https://ir.lib.uwo.ca/economicsresrpt

Part of the Economics Commons

Citation of this paper:

Palmer, John P.. "Barriers to Entry as a Measure of a Firm's Monopoly Power." Department of Economics Research Reports, 7124. London, ON: Department of Economics, University of Western Ontario (1971). 
RESEARCH REPORT 7124

BARRIERS TO ENTRY AS A MEASURE OF

A FIRM'S MONOPOLY PONER

by

John Palmer 
BARRIERS TO ENTRY AS A MEASURE OF A FIRM'S MONOPOLY POWER

by

John Palmer*

\section{Introduction}

Past work by Professors Bain [2] and Mann [9, 10] has demonstrated a strong positive correlation between a firm's rate of return and the barriers to entry (BTE) into the industry of that firm's principal output. This paper refines, extends, and updates their work.

The primary refinement made concerns diversification by large corporations. Most previous studies in industrial organization have acknowledged the existence of this diversification but have only partially allowed for its importance in attempted uses of concentration ratios or BTE. ${ }^{1}$ For example, Mann describes his procedure as follows:

\footnotetext{
"In order to minimize the effect of diversification by firms, an attempt was made to select firms which received at least 50 per cent of their sales revenue from the product of the industry in which they were placed. For most of the firms in the sample, there was no problem. However, there were a few, notably the tire and tube companies, which barely met the criterion. The results should, therefore, be interpreted with this limitation in mind." [10, p. 298]
}

In the present study, Mann's procedure could not be followed because many firms were included which did not satisfy the criterion of 50 per cent of their sales in one industry. It was believed that a firm with only 49 per cent of its sales in its principal industry might well have a degree of

$*$

The author, an assistant professor of economics at the University of Western Ontario, gratefully acknowledges helpful comments and assistance from Professors L. B. Fletcher, R. A. Mensing, and W. A. Merrill, all of Iowa State University, where most of the research for this paper was completed. 
monopoly power (for which BTE is a proxy) similar to that of a firm with 51 per cent of its sales in the same industry. In order to correct for this problem, a different criterion had to be devised.

Related to the above problem is the potential bias which could result from the assignment of each firm to only one industry. Such a procedure overlooks the monopoly power a firm may possess by way of its operations in industries from which less than 50 per cent of its total revenue is derived. As an example, consider the two hypothetical firms, A and B. Suppose that firm A has 51 per cent of its sales in an industry with very high (VH) BTE and 49 per cent in an industry with substantial (S) BTE, while firm B has 49 per cent of its sales in a VH-BTE industry and 51 per cent in an S-BTE industry. Mann would have placed firm $A$ in the $\mathrm{VH}$ category and firm $B$ in the $S$ category, even though the difference between the two is minimal. Ideally one would like to eliminate these potential problems in studying the relationship between monopoly power and profitability.

II. Procedure

The sample ${ }^{2}$ of firms studied was Fortune's list of the 500 largest industrial firms in 1965. Profit rates and sales information for each of these firms were taken from Moody's Industrial Manuals, 1961-1970, and Value Line, $1971 .^{3}$ Information concerning the height of BTE into the industries in which these firms operated was obtained from Bain [2], Mann [9, 10] and Shepherd [14]. For industries about which these three economists disagreed or for which none of them estimated the heights of BTE, independent estimates were made (see Appendix A). To allow for multi-industry output of the firms, a scheme was devised which weighted the percentage of a firm's sales in each industry by that industry's BTE. Industries with moderate-to-low (M-L) barriers 
were assigned the value of zero; with S barriers, 0.5; and with VH barriers 1.0. Next the per cent of a corporation's sales in each industry was multiplied by the value assigned to that industry's BTE, to measure the amount of monopoly power obtained by a firm from each of the industries in which it had sales. ${ }^{4}$ Then these weighted measures were summed to obtain $B$, a measure of each corporation's overall monopoly power.

Statistical contrasts were used to test the relationship between $B$ and rates of return for several reasons: (1) the strong likelihood of measurement errors in determining industries' BTE's and corporations' sales in each industry could be mitigated by dividing the $B$ measure into classes; ${ }^{5}$ (2) the original BTE estimates were made in terms of classes; and (3) the possible presence of heteroscedasticity ${ }^{6}$ could be corrected for using contrasts. Each contrast could be tested by subdividing the total error sum of squares into just that portion due to each contrast.

"Such a procedure insures that any particular treatment comparison will be tested against the appropriate error. That is, the expected value of the 'error mean square for testing $c_{k}{ }^{\prime}$ will contain the same components of variance (other than treatment effects) as the expected value of the mean square associated with $C_{k}$. In other words, if we are faced with different variances $\sigma_{i j}{ }^{2}(i=1, \ldots, b ; j=1, \ldots, t)$, the procedure of subdividing $E_{Y Y}$ [the error mean square] will insure that the expected mean squares for a particular comparison and its associated error will each contain the same linear combination of the $\sigma_{i j}$. This, of course, provides us with unbiased tests for the comparison under investigation." $[13, \mathrm{p} .377] .7$

The classes used for these contrasts were

$$
\begin{aligned}
& \mathrm{B}_{1}: 1.000 \geq \mathrm{B}>.667 \\
& \mathrm{~B}_{2}: .667 \geq \mathrm{B}>.333 \\
& \mathrm{~B}_{3}: . .333 \geq \mathrm{B} \geq 0 .
\end{aligned}
$$


To take account of the changing product mix of many firms over the nine-year period studied, especially due to merger activity during the latter half of that period, the sample period was subdivided into two periods, 1961-1965 and 1966-1969. B was calculated for each firm for each period, 8 as was the average rate of return.

Finally, because of the unequal number of observations in each class, the appropriate degrees of freedom for the denominator of the F tests is not immediately obvious. In this study, Satterthwaite's approximation was used to calculate these. 9

III. Results and Conclusions

The average rates of return for each class of monopoly power were $\bar{B}=12.36$, $\bar{B}_{2}=10.59$, and $\bar{B}_{3}=9.96$. The results of contrasts between these averages are presented in Table 1. Firms with the highest degree of monopoly power, $B_{1}$, had significantly higher average rates of return than firms with a medium degree of monopoly power, $\mathrm{B}_{2}$. And although firms with a medium degree of

Table 1. Contrasts testing the relationship $B$ and average rates of return.

\begin{tabular}{lcr} 
Contrast & df & F \\
\hline$B_{1}$ vs. $B_{2}$ & 9 & $11.321^{*}$ \\
$B_{2}$ vs. $B_{3}$ & 3 & 2.337 \\
$B_{1}$ and $B_{2}$ vs. $B_{3}$ & 13 & $13.944^{*}$ \\
\hline
\end{tabular}

monopoly power had higher average rates of return than firms with a low degree of monopoly power, $B_{3}$, this difference was not statistically significant. 
However, when the $B_{1}$ and $B_{2}$ classes were combined in a contrast against $B_{3}$, a significant difference was found. In general, it appears that firms in the $B_{1}$ class have enough monopoly power to substantially increase their rates of return, while those in the $B_{2}$ class do not necessarily have such power. Of course these results must be viewed with care. As Mann warned his readers,

\begin{abstract}
"But rates of return may be inadequate indicators of price-cost margins, the particular barrier-to-entry classification into which an industry was placed may be incorrect, the period [1961-1969] may be a short run for some of the industries in the sample, and some important sufficient conditions for the exercise of monopolistic pricing may not be fulfilled." [10, p. 300]
\end{abstract}

In particular, these potential problems may explain the lack of a clear conclusion with regards to firms in the $B_{2}$ class of monopoly power.

Finally, it must be emphasized that these results are statistical results. Any one firm may have a rate of return quite different from the average rate of return for all firms in its class. 


\section{Footnotes}

${ }^{1}$ A well-known exception is the work by Hall and Weiss [7], in which concentration ratios were weighted by the per cent of a firm's total employment in each industry.

2 If one is merely interested in the relationship between profits and monopoly power for 1961-1969, then the firms studied are a population, not a sample. In that case statistical inference tests like the ones used in this paper are unnecessary; the observed numbers and distributions are sufficient evidence on which to base conclusions.

If, though, one wishes to predict this relationship for another point in time, assuming that other conditions are approximately equivalent, the 1965 list of the 500 largest firms can be thought of as a sample from all possible lists over time. Alternatively, the 1965 list might be viewed as a sample from a conceptual population of all possible 1ists which might have existed in 1965, assuming that random elements determined the composition of the observed list for that year (cf. Gibrat's Law). If either of these latter lines of thought is adopted, statistical inference tests are not on $1 y$ justified, but they are mandatory for the drawing of conclusions from the observed data.

3 Because of data unavailability and because of mergers and acquisitions, not all 500 firms could be included in the sample. See Appendix B.

${ }^{4}$ Ideally, in studying the relationship between profits and BTE, one would like to weight the fraction of a corporation's profits generated in each industry by that industry's BTE. Unfortunately such a disaggregation of profits is only rarely reported, possibly because of the indeterminacy arising from joint products.

${ }^{5}$ See Johnston $[8$, p. 149].

${ }^{6}$ See Hall and Weiss [7].

${ }^{7}$ An explanation of the procedure is provided by 0stle [13, p. 378]

${ }^{8}$ The data on B are provided for each firm in Appendix B.

${ }^{9}$ See 0stle [13, pp. 302-303]

10 W. G. Shepherd, private communication, May 17, 1971. 


\section{$\underline{\text { References }}$}

${ }^{1}$ Advertising Age 40, no. 42: 49-60, "Magazines 1969." 1969.

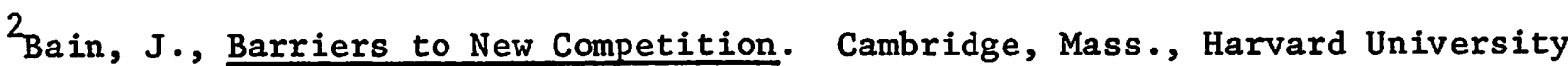
Press, 1965.

3 Federal Trade Commission, Bureau of Economics, "Comparable Concentration Ratios for 213 Manufacturing Industries Classified by Producer and Consumer Goods and Degree of Product Differentiation 1947, 1954, 1958, and 1963." Washington, D.C., 1967. 1968.

${ }^{4}$ Financial World 130 , no. 14: 11-12, "Regional Brewers Battle for Survival."

5orbes 104: no. 6: 95, "Battle for Survival." 1969.

${ }^{6}$ Fortune 74 , no. 2: 232-249, "The 500 Largest U.S. Industrial Corporation." 1966 .

7 Hall, M. and Weiss, L., "Firm Size and Profitability." R. E. Stat. 49 : 319-331. 1967 .

${ }^{8}$ Johnston, J., Econometric Methods. New York, McGraw-Hill Book Co., Inc., 1963.

9 Mann, H., "Asymmetry, Barriers to Entry, and Rates of Return in Twentysix Concentrated Industries, 1948 to 1957." Western Economic Journa1. 8: 8689. 1970 .

10 , "Seller Concentration, Barriers to Entry, and Rates of Return in Thirty 'Industries, 1950-1960." R. E. Stat. 48: 296-307. 1966.

${ }^{11}$ Marketing / Communications 298, no. 1: 26-29, "Sch1itz sets pace for beer's big 3." 1970 .

12 Moody's Industrial Manual, $1961-1970$.

${ }^{13}$ Ostle, B., Statistics in Research (2nd ed.). Ames, Iowa, The Iowa State University Press, 1963.

${ }^{14}$ Shepherd, W., Market Power and Economic Welfare. New York, Random House, Inc., 1970 .

${ }^{15}$ Standard and Poor's Industry Surveys, 1971.

${ }^{16}$ The Value Line Investment Survey, 1971. 
Appendix A. Barriers to Entry to Various Industries

Whenever possible, previous studies were relied upon to provide

information on barriers to entry to these industries. The four primary sources were Bain [2], Mann [9, 10], and Shepherd [14]. Supporting evidence was frequently drawn from a Federal Trade Commission (FTC) study done in 1967 [3] .

Bain and Mann discuss four basic types of barriers to entry. These are

1. scale barriers. The cost curves for firms in a particular industry may be downward sloping until a very large rate of output is reached. This rate of output may be so large relative to the total demand for the product that only a few firms can profitably exist in the industry. Entry by another firm would reduce the market shares of all firms and raise their average costs so that none of them could be profitable. Potential entrants, recognizing this state of affairs, will try to avoid unprofitable entry, but the incumbents may still be enjoying monopoly profits.

2. product differentiation barriers. If consumers are strongly attached to existing brands of a product, either because they find the relevant information difficult to acquire or comprehend or because of large advertising expenditures, entrants to this industry will be forced to sustain burdensome advertising expenditures if they wish to capture a profitable share of the market.

3. absolute cost barriers. If one firm or a few firms control necessary patents or natural resources or have special technical secrets, entry into this industry will be effectively impeded.

4. capital barriers. In undertaking a business venture, a firm will require capital in the form of plant, equipment, and inventories. If the capital market is imperfect, large capital requirements in an industry may be a barrier to entry.

This basic framework of analysis has been followed in this appendix whenever necessary and / or possible.

In the following tables are listed industries with very high (VH), substantial (S), or moderate-to-low (M-L) barriers to entry, respectively. The codes in parentheses following each industry refer to the source(s) in which the classification was made. These sources and their codes are: 


$\begin{array}{lll}\text { B. } & \text { Bain } & {[2]} \\ \text { MR. } & \text { Mann } \quad[10] \\ \text { MW. } & \text { Mann } \quad[9] \\ \text { Sh. } & \text { Shepherd [14] } \\ \text { P. } & \text { Palmer, this study. }\end{array}$

An asterisk following an industry indicates a disagreement among sources as to the appropriate class for that industry. Resolutions of these disagreements along with explanations of all classifications coded "P" follow these first three tables. When asked his opinion of the disagreements, Shepherd responded, "I regard all estimates of entry barriers as unavoidably subjective in some degree..." 10 After attempting the estimates himself, one can only agree. 
Table 2.

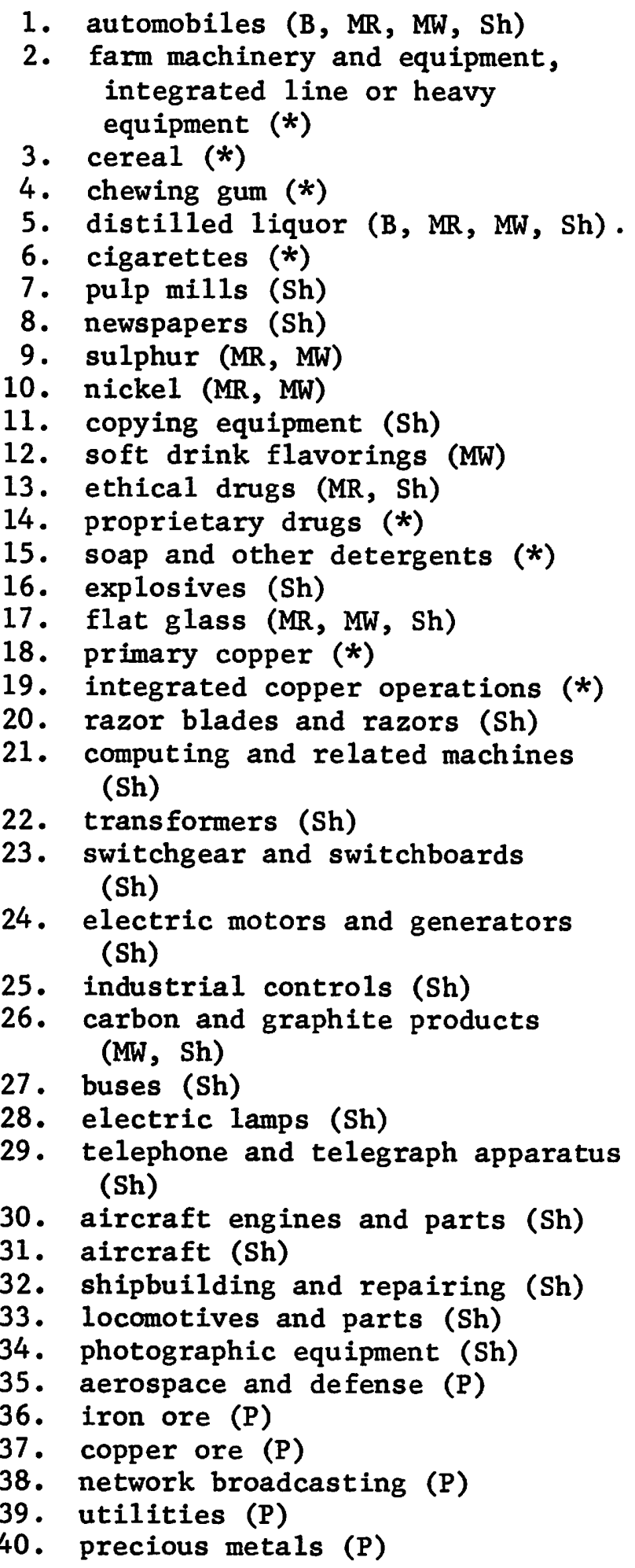


1. light farm equipment (*)

2. blended and prepared flour mixes ( $\mathrm{Sh}$ )

3. bread and related products (*)

4. chocolate and cocoa products (Sh)

5. sanitary paper products (Sh)

6. periodicals (*)

7. alkalies and chlorine (MW, $\mathrm{Sh})$

8. industrial gases ( $\mathrm{Sh}$ )

9. intermediate coal tar products (Sh)

10. inorganic pigments (Sh)

11. other inorganic chemicals (Sh)

12. organic chemicals (Sh)

13. synthetic rubber (Sh)

14. other man-made fibers (Sh)

15. toilet preparations (Sh)

16. petroleum refining ( $B, M R, S h$ )

17. tires (*)

18. other pressed and blown glass (*)

19. cement $(*)$

20. blast furnaces and steel mills (*)

21. cold-finished steel shapes (*)

22. steel pipe and tube (*)

23. primary zinc ( $\mathrm{Sh}$ )

24. primary aluminum ( $M R, M W, S h$ )

25. copper rolling and drawing (*)

26. aluminum rolling and drawing (Sh)

27. nonferrous wire drawing, etc. (Sh)

28. metal cans (*)

29. shoe machinery (MR, MW)

30. sugar (MW, Sh)

31. steel power boilers (Sh)

32. safes and vaults (Sh)

33. steam engines and turbines (Sh)

34. internal combustion engines (Sh)

35. construction machinery ( $\mathrm{Sh}$ )

36. elevators and escalators (Sh)
37. industrial trucks and tractors (Sh)

38. rolling mill machinery (Sh)

39. paper industries machinery (Sh)

40. typewriters (*)

41. household cooking equipment (Sh)

42. household refrigerators (Sh)

43. household laundry equipment (Sh)

44. beer (*)

45. lumber (Sh)

46. fertilizers (Sh)

47. radios and televisions ( $\mathrm{Sh}$ )

48. broadcasting equipment (Sh)

49. electron tubes (Sh)

50. cathode ray picture tubes (Sh)

51. storage and primary batteries (Sh)

52. X-ray apparatus (Sh)

53. hard surface floor coverings (*)

54. heavy industrial machinery (Sh)

55. air conditioning and heating equipment ( $P$ )

56. plastic production (P)

57. natural gas (P)

58. heavy auto parts (P)

59. paperboard (P)

60. local broadcasting (P)

61. vehicle rental $(P)$

62. natural resources $(P)$

63. office machines (P)

64. insecticides (P)

65. steamship operations (P)

66. lawn and garden equipment (P)

67. guns (P)

68. Soup (P)

69. baby food (P)

70. computer software (P)

71. credit cards (P)

72. refractory materials (P)

73. mobile homes (P)

74. cigars (P)

75. silverware and plated ware (P) 
Table 4. Industries with Moderate-to-Low Barriers to Entry

1. small metal products (Sh)

2. wooden furniture (Sh)

3. fluid milk (Sh)

4. wet corn milling (Sh, MW)

5. biscuits, crackers and cookies $(*)$

6. rayon (*)

7. flour (B, MR, Sh)

8. footwear (Sh)

9. sewing machines (Sh)

10. woolen and cotton textiles (MR, Sh)

11 clothing (MR, Sh)

12. glass containers (*)

13. brick and structural tile (Sh)

14. gypsum products (*)

15. abrasive products (Sh)

16. electrometallurgical products ( $\mathrm{Sh}$ )

17. foundries (Sh)

18. secondary non-ferrous metals $(\mathrm{M}-\mathrm{L})$

19. canned fruits and vegetables (B, MR, Sh)

20. bituminous coal (MR)

21. transportation equipment, hardware (Sh)

22. metal plumbing fixtures (Sh)

23. ball and roller bearings ( $\mathrm{Sh}$ )

24. household vacuum cleaners (Sh)

25. books $(*)$

26. corrugated containers (Sh)

27. engine electrical equipment (Sh)

28. surgical appliances and supplies ( $\mathrm{Sh}$ )

29. meatpacking (B, MR, Sh)

30. printing ( $\mathrm{Sh}$ )

31. quarrying ( $P$ )

32. plastic fabrication (P)

33. paperboard products (P)

34. packaging materials (P)

35. light auto parts (P)

36. dairy products $(P)$

37. asbestos ( $P$ )

38. real estate (P)
39. adhesives ( $P$ )

40. tape and allied products (P)

41. advertising services ( $P$ )

42. educational and training services (P)

43. protection systems (P)

44. leisure products (P)

45. retailing ( $P$ )

46. crafts, games, and toys (P)

47. printing ink (P)

48. restaurants (P)

49. insurance $(P)$

50. finance $(P)$

51. rugs and carpets (P)

52. writing equipment (P)

53. ophthalmic goods (P)

54. soft drink bottlers (P) 
Farm machinery and equipment (VH2, S1). Bain [2] and Mann [9, 10] place this industry in the substantial category, but Bain's discussion suggests that the industry could well be segmented as was done here. For heavy farm equipment such as tractors, combines, etc., the optimal scale of operations is ten to fifteen percent of the national market $[2, p, 260]$, a very high scale barrier, and there are significant multiplant economies [2, p. 262]. There also appear to be some economies for full-1ine integrated operations, but the barriers to entry are lower for small machinery [2, p. 262].

Cereal (VH3). The product differentiation barrier is so high that the industry is placed in the VH class. From Mann, "The marketing of new brands is very expensive. One estimate indicates that approximately $47 \%$ of the sales revenue earned in the first year on fourteen new brands introduced between 1957 and 1961 was spent on advertising in the major media" [9, unpublished appendix]. Shepherd placed cereals in the substantial barrier class. Chewing gum (VH4). Mann [10] indicates a VH product differentiation barrier which is high enough to pull the industry into the VH over-all class. Shepherd placed chewing gum in the substantial class. 
Soap and detergents (VH15). Bain decided that the product differentiation barrier is VH and the capital barrier is substantial (p. 169). He suggested that since innovation is quite likely in this industry, an avenue for entry was available through new products. This possible means of entry was sufficient, he thought, to put the firm in the substantial class rather than the VH class.

Shepherd's classification of VH was accepted for the present study because new firms do not seem to have used the innovation route very successfully during the 1960's. In fact, the proliferation of enzyme products was begun by Colgate-Palmolive, leading one to believe that perhaps innovation and research and development may be used by incumbents to create another barrier to entry.

Cigarettes (VH6). Here again the indication [2, pp. 286-288] is that the $\mathrm{VH}$ product differentiation barrier is sufficient to term this industry as having VH barriers, but Shepherd termed the barriers substantial.

Proprietary and ethical drugs (VH13, VH14). Mann [10] and Shepherd both place ethical drugs in the VH category. Proprietary drugs were placed there also because of their high product differentiation barrier. Copper and copper products (VH18, VH19, S25). Bain (p. 171) places all copper operations in the substantial class, but allows for the possibility that due to scarcity and the close control of natural resources, the absolute cost barrier may be $\mathrm{VH}$. He further points out that because of economies of vertical integration, and optimal scale of a firm is $10 \%$ of the national output (p. 248). On the basis of this evidence, Shepherd was followed to some extent in the present study with primary copper and integrated operations placed in the VH class, and copper rolling and drawing in the substantial class. The control of ore deposits has less impact on the secondary copper 
operations because of reclamation and use of scrap copper.

Bread and related products (S3). Mann [10] called the barriers M-L in this industry even though, "For entrants other than grocery chains, economies of scale are a very important barrier to entry, largely because the relevant markets are small relative to the optimal size plant," [p. 304]. This high scale barrier coupled with the fact that the number of bakeries had declined from 5,984 in 1947 to 4,339 in 1963 [3, p. 1] led to agreement with Shepherd that the barriers to entry in the bread industry probably substantial.

Periodicals (S6). There is a serious problem in the periodicals industry of defining the relevant market. Women's magazines probably do not compete much with children's magazines or financial magazines, but they all probably compete, to some extent with newspapers, television, radio, and perhaps even general news magazines. Shepherd at one point ( $p .126)$ places "general periodicals" in the VH class, but at another point (pp. 274-275) places periodicals in the substantial class.

The problem is further compounded by evidence [1] that in each specialized area the number of periodicals has increased rapidly during the past decade, but this growth has been due to specialization and product differentiation. It may still be that the barriers to entry into the subindustry of general, nationwide news and consumer magazines are very high. This possibility has been rejected in the present study because these general periodicals must compete on nearly equal terms with various specialized periodicals (and other news and entertainment sources) for the readers' time as well as money.

Tires (S17). Bain put this industry in the M-L class partly because of its low scale barrier ( $p .238$ ), and partly because of the comparative ease of entry to the replacement field. The industry was moved up a class in this 
study because of the possible control of natural resources, because of the growth of the product differentiation barrier, and because of the high barrier (acknowledged by Bain) to the original equipment field. This last factor will grow in importance in the future because of the development of longer-lasting polyester cord tires, decreasing the demand for replacement tires.

Pressed and blown glass (\$18). Shepherd placed this industry in the VH category. The evidence provided by the FTC, however, was judged as insufficient to justify placing the industry above the upper range of the substantial category:

Table 5. Some Structural Characteristics of the Pressed and

$$
\text { Blown Glass Industry } \quad[3, \mathrm{p}, 9]
$$

Year Number of Firms

concentration ratios

1947

107

1954

1958

255

111

1963

75

\begin{tabular}{ccc}
\multicolumn{3}{c}{ concentration ratios } \\
\hline 4-firm & 8 -firm & 20 -firm \\
51 & 65 & 80 \\
67 & 77 & 88 \\
64 & 79 & 90 \\
68 & 81 & 93
\end{tabular}

Cement (S19). Although the cement industry was placed in the M-L class by Bain, Mann [10] reports that the optimal scale of operations had grown so much relative to the regional markets during the 1950 's that cement probably now belongs in the substantial class.

Stee1, cold-finished steel shapes, steel pipe and tube (S20, S21, S22). Shepherd estimates the barriers in these industries as VH, but the evidence from Bain and the FTC on the steel industry overwhelmingly support Bain's estimation of only substantial barriers. 
The only evidence that supports placing steel in the $\mathrm{VH}$ class is the possibly VH barriers due to scarcity and the control of natural resources [2, p. 271] . Offsetting this possibility are the small optimal plant size [2, p. 236], only slight multiplant economies [2, p. 254], only slight product differentiation barriers [2, p. 265], and low selling costs [2, p. 179]. Furthermore, from 1958 to 1963 (the only years for which data are available in the FTC study), the number of firms in the steel industry increased from 148 to 162 . During that same time period, the 4-firm concentration ratio in the steel industry declined from .53 to .50 [3, p. 10].

In opposition to Shepherd's estimates, the secondary steel industries included here are placed in the substantial category. The reasons for this classification are that steel producers (into which the barriers to entry are only substantial) should find vertical entry into these industries relatively easy. In addition, these secondary industries are frequently able to use scrap metal and are, therefore, less dependent on a closely held natural resource. A final piece of supporting evidence is that the concentration ratios in these industries ( .34 and .26 , respectively) are even lower than that of the basic steel industry [14, p. 274].

Metal Cans (S28). Before 1950, Bain thought, the metal can industry might have had substantial barriers to entry. The anti-trust suit of that year forbidding tying contracts, he believed, would lower these barriers enough so that they would only be moderate. As can be seen from Table 6, this belief was probably not borne out. 
Table 6. Some Structural Characteristics of the Metal Can

$$
\text { Industry } \quad[3, \mathrm{p}, 11]
$$

\begin{tabular}{lcccc} 
Year & Number of Firms & \multicolumn{3}{c}{ concentration ratios } \\
\cline { 3 - 5 } & & $4-$ firm & 8 -firm & 20 -firm \\
1947 & 102 & 78 & 86 & 94 \\
1954 & 109 & 80 & 88 & 96 \\
1957 & 84 & 80 & 89 & 97 \\
1963 & 99 & 74 & 85 & 95
\end{tabular}

The structure of the metal can industry does not seem to have changed much since 1947.

It should be pointed out, too, that the concentration ratios significantly understate the monopoly power of the firms in this industry. Because metal cans are bulky, their high transportation costs relative to their value makes their relevant market regional rather than national in scope. Within each region the concentration ratios may be much higher and the barriers to entry may also be higher.

Typewriters (S40). The placement of the typewriter industry by Shepherd into the M-L category is not supported by the FTC data in Table 7 . The persistently small number of firms and large concentration ratios suggest

Table 7. Some Structural Characteristics of the Typewriter

$$
\text { Industry } \quad[3, \mathrm{p}, 13]
$$

\begin{tabular}{lcccc} 
Year & Number of Firms & \multicolumn{3}{c}{ concentration ratios } \\
\cline { 3 - 5 } & & $4-$ firm & 8 -firm & 20 -firm \\
1947 & 23 & .79 & .96 & 1.00 \\
1954 & 15 & .83 & .99 & 1.00 \\
1958 & 15 & .79 & .99 & 1.00 \\
1963 & 17 & .76 & .99 & 1.00
\end{tabular}

the existence of at least substantial barriers to entry. It seems unlikely that such an industry structure could be maintained for long without the existence of significant barriers to entry. 
Beer ( $\$ 44)$. Mann [10] placed this industry in the M-L class because only insignificant scale economies seemed evident and because, "One consumer survey indicates that beer-drinkers do not show a marked preference for nationally advertised beers" ( $p .305$ ). Additional facts cast some doubt on this decision and suggest that the beer industry has substantial barriers to entry.

Most important of these facts are the data from the FTC in Table 8 showing that the big brewers are becoming bigger while the small brewers are finding it difficult to remain profitable. Suggested reasons for this phenomenon are price wars, seasonal fluctuations, high fixed expenses, and encroachment by industry giants [4]. These reasons further suggest that the capital barrier (as opposed to the scale barrier) is fairly high because of seasonally fluctuating inventories. They also suggest that the product differentiation barrier is growing as the nationwide industry giants encroach upon the regional markets of the small brewers.

Additional evidence of growing barriers to entry to the beer industry are that the top two firms accounted for $31 \%$ of beer sales in 1969 [11] and that regional brewers find it difficult to go national [5].

Table 8. Some Structural Characteristics of the Malt Liquor Industry $\quad[3, p .2]$

Year Number of Firms concentration ratios

1947

1954

1958

1963
404

263

211

171

\begin{tabular}{ccc}
\multicolumn{3}{c}{ concentration ratios } \\
\hline 4-firm & $8-$ firm & 20 -firm \\
21 & 30 & 44 \\
27 & 41 & 60 \\
28 & 44 & 68 \\
34 & 52 & 78
\end{tabular}


Hard surface floor coverings (S53). Mann [9] is unconvincing in his reasons for having placed this industry in the substantial class. He says that the optimal scale of operations may be around $10 \%$ of the national output, but he also points out that, "The cost curves below minimum optimal scale in these three product lines may be fairly shallow, though, because the major study of this industry does not list economies of scale to the plant or to the firm as a significant deterrent to entry and there is no apparent tendency for small plants to disappear over time" [9, unpublished appendix] .

Mann further says that the product differentiation barrier seems important, but there appears to be no sizeable absolute cost barrier and capital requirements are only moderate. One is tempted, on the basis of these facts, to agree with Shepherd that the barriers to entry here are only $\mathrm{M}-\mathrm{L}$.

The FTC data (Table 9) are strong enough, though, to tip the scales in Mann's favor. On the theory that small numbers and high concentration ratios cannot long exist in an industry without significant barriers to entry, one must finally place the hard surface floor covering industry in the substantial category.

Table 9. Some Structural Characteristics of the Hard Surface Floor Coverings Industry [3, p. 16] Year Number of Firms concentration ratios

1947

1954

1958

1963
14

10

11

15

\begin{tabular}{ccc}
\multicolumn{3}{c}{ concentration ratios } \\
\hline 4-firm & 8 -firm & 20 -firm \\
.80 & .95 & 1.00 \\
.87 & .96 & 1.00 \\
.83 & .96 & 1.00 \\
.87 & .98 & 1.00
\end{tabular}


Biscuits, crackers, and cookies (M-L5). Mann's classification of this industry as having substantial barriers to entry is questionable. He states that, "...economies of scale appear to be unimportant" [10, p. 304], and that capital requirements are moderate [p. 304]. It also would seem that the absolute cost barriers are low. The only substantial barrier in this industry is that of product differentiation. As stated, this evidence is not convincing on whether the industry has substantial or moderate-to-low barriers. The argument for M-L (Shepherd's choice) is more persuasive when it is realized that biscuits, etc., are less perishable than bread. As a result, a potential entrant must capture a smaller share of the market to be profitable in biscuits than in bread. He can ship his product farther, and it will last longer on the shelves.

Rayon (M-L6). The barriers in the rayon industry were termed substantial by Shepherd, but Bain's classification of the industry as M-L was given more weight in the present study. There may have been some absolute cost barrier to entry due to secret techniques as the industry was developing [2, p. 155], but by 1960 , these techniques were fairly readily available. There are no product differentiation barriers [2, p. 137].

Glass containers (M-L12). Mann [10] put this industry in the M-L category because "Economies of scale do not seem to be important..." [p. 304], and there is "...1ittle room for product differentiation" [p. 304]. He mentions also that the patent control, which provided a very high barrier, was effectively diminished by an anti-trust suit in 1946 . If these statements are correct, there is no reason for Shepherd's classification of VH. Gypsum products (M-L14). Shepherd placed the gypsum industry in the substantial class, but after U.S. Gypsum was required to desist from exclusively licensing its patents in a 1951 anti-trust suit, the absolute cost 
barriers became negligible [2, pp. 266-268].

Books (M-L25). Shepherd classed the barriers substantial here, but this classification was rejected because, while through copyright laws each title has its own monopoly, there are generally many competitors in each subject area. This widespread competition is evidenced by the FTC data presented in Table 10.

Table 10. Some Structural Characteristics of the Book Industry [3, p. 6] Year Number of Firms concentration ratios

1947

1954

1958

1963
635

804

883

936 8-firm

.29

.32

.29

.33
20 -firm

.48

.51

.48

.56

Aerospace and defense (VH35). This industry was placed in the VH class because of its obvious similarities to the aircraft industry (VH31). Iron and copper ore (VH36, VH37). The control of scarce natural resources [2, p. 171] seemed sufficient to justify placing these industries in the $\mathrm{VH}$ class.

Network broadcasting (VH38). The economies of scale seem to be such that the existing firms in this industry have nearly natural monopoly power. The failure of recent attempts to enter it also suggest a VH classification. Utilities (VH39). These are assumed to have natural or state-endowed monopoly power.

Precious metals (VH40). The general technology in these industries is similar to that of primary copper (VH18), and their smaller markets increases their scale barriers. 
Air conditioning and heating equipment (S55). These products were deemed sufficiently similar to heavy industrial machinery (S54) and large consumer appliances (S41, S42, S43) that they were placed in the substantial class.

Plastic production and fabrication (S56, M-L32). Plastic production was equated with chemicals $(\mathrm{S} 11, \mathrm{~S} 12)$ and put in the class with substantial barriers. Plastic fabrication, though, depends less on patents, secret technologies, and scale barriers to entry. Consequently its barriers were termed $\mathrm{M}-\mathrm{L}$.

Natural gas (S57). The conditions in this industry were believed to be enough similar to those in the petroleum industry (S16) to justify placing it in the substantial class. One significant difference, though, is that natural gas is sold in large amounts to regional distributors who have natural monopolies. This situation gives rise to bilateral monopoly conditions, which may or may not, depending on relative bargaining powers, affect the performance in the natural gas industry.

Auto parts $(S 58, M-L 35)$. This industry was segmented into the two groups because heavy auto parts more closely resemble heavy industrial equipment (S54) and internal combustion engines (S34). Light auto parts are likely to be similar to engine electrical equipment (M-L27) and small metal products $(\mathrm{M}-\mathrm{L} 1)$

Pulp, paper, and paper products (VH7, S5, S59, M-L26, M-L33, M-L34). These various subindustries are quite troublesome. Shepherd's placement of pulp mills in the $\mathrm{VH}$ class was accepted. So was his placement of sanitary paper products in the substantial class. The rest of the products seemed to fall into the two broad groups of paper or paperboard manufacturing and paper or paperboard products. The former group was placed in the substantial class because of its closer vertical connection with lumber supplies and its greater scale barriers than the latter. 
Local broadcasting ( 560 ). The growth of the markets, the increasing use of UHF channels, and the recent license changes by the FCC were all factors influencing the decision to place this industry in the substantial class.

Vehicle rental (S61). The barriers to entry into this industry were judged to be substantial rather than $\mathrm{VH}$ because the product differentiation and capital barriers are lower than those in the automobile industry.

Natural resources (S62). This industry is such a conglomeration of activities that an estimation of its barriers to entry must be tenuous at best. This estimation was attempted only because no further sales disaggregation is provided for IT and T. The substantial classification was finally decided upon because most ore activities are VH (VH36, VH37), while lumber and cement are substantial (S45, S19), and gypsum (M-L14) and asbestos (M-L37) are M-L. Substantial seemed a reasonable average of these barriers. Office machines (S63). Office machines were considered similar to typewriters ( 540$)$ and were placed in the same category.

Insecticides (S64). These appear to be related to chemicals (S11, S12) and fertilizers (S46) and consequently were assigned to the substantial category.

Steamship operations (S65). This industry was finally assumed to have substantial barriers because of its capital requirements, but its international market and competition may be strong enough that it should have been placed in the $M-L$ category.

Lawn and garden equipment (S66). Because light farm equipment (S1) and large consumer appliances (S41, S42, S43) were all in the substantia1 class, the lawn and garden equipment industry was put there, too. 
Guns (S67). This industry also seemed similar enough to the large consumer appliance industries ( $541,542,543)$ that it was placed in the substantial class.

Soup and baby food (S68, S69). Bain, Mann (1966), and Shepherd a11 agree that generally canned fruits and vegetables (M-L19) belong to the $M-L$ category. These two products seemed different, though, because of specialized product differentiation, and were elevated by this study to the substantial category. In both cases there are only two firms controlling very large shares of the market.

Computer software (S70). Since computer software consists basically of paper products and paperboard products, it might upon initial consideration be assigned to the M-L class, but the tying contracts of software to hardware throughout much of the $1960^{\prime}$ 's suggested that it should properly be placed in the substantial class, at least for that time period.

Credit cards (S71). The capital barriers and the problems of establishing an organization for the clearance of accounts were deemed sufficiently significant to justify the placement of the credit card industry in the substantial category.

Refractory materials (S72). The declining number of firms in this industry and its slightly increasing concentration ratios led to the decision to assign it to the substantial barrier class (Table 11).

Table 11. Some Structural Characteristics of the clay

$$
\text { Refractories Industry [3, p. 9] }
$$

Year Number of Firms

concentration ratios

1947

1954

1958

1963
108

113

104

80

4-firm
.41
.43
.43
.41

.41 8-firm

.57

.60

.61

.60 20-firm

.76

.79

.81 
Mobile homes (S73). This industry was put in the substantial class rather than the $\mathrm{VH}$ class because its scale and product differentiation barriers are more nearly like those of the truck industry (S37) than the automobile industry (VH1).

Cigars (S74). The cigar industry has experienced a sizeable decrease in the number of firms and a sizeable increase in its concentration ratios (Table 12). The relatively large number of remaining firms and the lower product differentiation barriers here than in the cigarette industry were nevertheless deemed sufficient for placing cigars in the substantial class.

Table 12. Some Structural Characteristics of the Cigar

$$
\text { Industry } \quad[3, p, 9]
$$

Year Number of Firms

concentration ratios

1947

1954

1958

1963
765

375

247

164

\begin{tabular}{lcc}
\hline $4-$ firm & 8 -firm & 20 -firm \\
.41 & .57 & .76 \\
.44 & .64 & .80 \\
.54 & .75 & .86 \\
.59 & .81 & .92
\end{tabular}

Silverware and plated ware (S75). The only slightly declining number of firms (increasing since 1954) and the declining concentration ratios shown in Table 13 suggest that the barriers to entry to this industry may be substantial but are not high enough to be termed VH.

Table 13. Some Structural Characteristics of the Silverware and Plated Ware Industry $\quad[3, \mathrm{p} .15]$

\begin{tabular}{ccccc} 
Year & Number of Firms & \multicolumn{3}{c}{ concentration ratios } \\
\cline { 3 - 5 } & & 4 -firm & 8 -firm & 20 -firm \\
1947 & 221 & .61 & .72 & .82 \\
1954 & 190 & .61 & .72 & .83 \\
1958 & 198 & .54 & .67 & .79 \\
1963 & 201 & .55 & .66 & .81
\end{tabular}


Quarrying (M-L31). Because the number of firms in the cut stone and stone products industry has increased from 624 in 1947 to 857 in 1963 $[3, p, 10]$, and because the control of scarce natural resources seems unimportant, this industry was placed in the $M-L$ class.

Dairy products (M-L36). This industry was related to fluid milk (M-L3), biscuits, etc., (M-L5), and canned fruits and vegetables (M-L19) and placed in the $\mathrm{M}-\mathrm{L}$ category.

Asbestos (M-L37). While there is some control of the natural resources of this industry, and there are some attempts at product differentiation, the general structure of the asbestos industry probably does not differ significantly from that of the gypsum industry (M-L14).

Real estate (M-L38). Land development may have some semblance of natural monopoly powers associated with any single development, but the range of substitutes seems broad enough, especially for firms operating on a nationwide basis, to merit the assignment of this industry to the M-L class. Adhesives (M-L39). These seemed somewhat similar to abrasives (M-L15) and were placed in the same category. This decision was also based on considerations of different types of adhesives (e.g., chemical, biological), all of which compete to some extent.

Tape and allied products (M-L40). This industry appears to be related to that of plastic fabrication $(M-L 32)$ and hence was assigned to the $M-L$ class.

Advertising, educational, and training services (M-L41, M-L42). These various services were placed in the M-L barrier class because of their low capital, scale, and absolute cost barriers. Product differentiation, though it exists, also seems unimportant as a barrier to entry. 
Protection systems (M-L43). Protection systems are constructed primarily of small metal products (M-L1) and metal plumbing fixtures (M-L22), placing them in the M-L class of barriers to entry.

Leisure products (M-L44). On the assumption that generally these involved small metal parts (M-L1), textiles (M-L10), or plastic fabrication (M-L32), leisure products were for the most part assigned to the $M-L$ category. Exceptions were made in the cases of guns (S67), boats, and bowling alleys and pinsetters because these more nearly represented large consumer appliances (s41, s42, S43) or heavy industrial machinery (S54).

Retailing and restaurants (M-L45, M-L48). The barriers to entry to these industries were termed M-L because of their relatively low capital, scale, and absolute cost barriers. The growth of chain outlets and franchises may have foreclosed entry slightly, but a growing and shifting population provides a constantly growing and changing source of demand to be tapped by potential entrants.

Crafts, games, and toys (M-L46). This industry consists primarily of small metal products $(M-L 1)$, paperboard products $(M-L 33)$, and plastic fabrication (M-L32). Additional evidence from the FTC concerning the games and toys industry is relevant:

Table 14. Some Structural Characteristics of the Games and

$$
\text { Toys Industry } \quad[3, p, 15]
$$

Year Number of Firms concentration ratios

1947

1954

1958

1963
830

872

845

767

\begin{tabular}{lcc}
\multicolumn{3}{c}{ concentration ratios } \\
\hline 4-firm & 8 -firm & 20 -firm \\
.20 & .29 & .44 \\
.18 & .25 & .40 \\
.13 & .22 & .35 \\
.15 & .25 & .43
\end{tabular}


Printing ink (M-L47). The number of firms in this industry is no higher than the number of firms in some of the industries assigned to the substantial class, but the growth in the number of firms, shown in Table 15, and the declining concentration in the industry strongly support the decision to assign it to the $\mathrm{M}-\mathrm{L}$ class.

Table 15. Some Structural Characteristics of the Printing

$$
\text { Ink Industry } \quad[3, \mathrm{p} .8]
$$

\begin{tabular}{ccccc} 
Year & Number of Firms & \multicolumn{3}{c}{ concentration ratios } \\
\cline { 3 - 5 } & & $4-$ firm & 8 -firm & $20-$ firm \\
1947 & 151 & .57 & .69 & .81 \\
1954 & 188 & .54 & .65 & .79 \\
1958 & 193 & .53 & .65 & .78 \\
1963 & 216 & .48 & .63 & .77
\end{tabular}

Insurance $(M-L 49)$. This industry was tentatively put in the $M-L$ class because insurance firms seem abundant, with small ones entering regional markets with relative ease.

Finance $(\mathrm{M}-\mathrm{L} 50)$. In a very general sense, this industry includes banks, savings and loan institutions, credit unions, finance companies, loan sharks, and insurance companies. While entry into some of these forms of financial institutions is impeded by federal and state regulations, entry into other competing segments of the industry is relatively easy.

Rugs and carpets (M-L51). Because furniture (M-L2) and textiles (M-L10) were classed in the M-L category, so were rugs and carpets.

Writing equipment (M-L52). Bain ( $p .169)$ thought that the only significant barrier to entry into the high-quality fountain pen industry was that of product differentiation. The writing equipment industry of the 1960's involved primarily ball-point pens, though, and in this case the scale and capital 
barriers are even lower than they were for fountain pens. Product differentiation still appears to have some importance, but the proliferation of littleknown brands has been significant enough that the industry barriers were classified as M-L.

Ophthalmic goods (M-L53). Product differentiation in this industry appears to be relatively unimportant [3, p. 15]. The data on the number of firms and concentration are mixed (see Table 16), but the final decision was to place the industry in the lowest class.

Table 16. Some Structural Characteristics of the Ophthalmic

$$
\text { Goods Industry } \quad[3, \mathrm{p} .15]
$$

\begin{tabular}{ccccc} 
Year & Number of Firms & \multicolumn{3}{c}{ concentration ratios } \\
\cline { 3 - 5 } & & 4 -firm & 8 -firm & 20 -firm \\
1947 & 175 & .58 & .69 & .80 \\
1954 & 223 & .54 & .63 & .75 \\
1958 & 216 & .52 & .62 & .74 \\
1963 & 211 & .53 & .62 & .77
\end{tabular}

Soft drink bottlers (M-L54). In addition to being somewhat related to other food processing industries, the bottling industry was placed in the $M-L$ category because of its large number of firms and low concentration ratios. The data in Table 17 suggest that the barriers are growing in this industry, probably because of franchising by more popular national brands, but the sheer numbers involved still seem to warrant this decision.

Table 17. Some Structural Characteristics of the Soft-

$$
\text { Drink Bottling Industry [3, p. 2] }
$$

Year Number of Firms

concentration ratios

$1947 \quad 5169$

1954

1958

1963

\begin{tabular}{lcc}
\hline 4-firm & $8-$ firm & 20 -firm \\
.10 & .14 & .20 \\
.10 & .14 & .21 \\
.11 & .15 & .22 \\
.12 & .17 & .24
\end{tabular}


APPENDIX B. The Firms Studied and Their Monopoly Power in 1965 and 1969

\begin{tabular}{|c|c|c|c|c|c|}
\hline Corporation & $\begin{array}{l}\text { Rank by } \\
\text { Sales } \\
1965 \\
\end{array}$ & $\begin{array}{c}\text { B } \\
1965 \\
\end{array}$ & $\begin{array}{c}\text { B } \\
\text { Classes } \\
1965 \\
\end{array}$ & $\begin{array}{c}\text { B } \\
1969 \\
\end{array}$ & $\begin{array}{c}\text { B } \\
\text { Classes } \\
1969 \\
\end{array}$ \\
\hline General Motors & 1 & $.95^{\circ}$ & 1 & .95 & 1 \\
\hline Ford & 2 & .89 & 1 & .89 & 1 \\
\hline Standard Oil (NJ) & 3 & .50 & 2 & .50 & 2 \\
\hline General Electric & 4 & .65 & 2 & .67 & 2 \\
\hline Chrysler & 5 & .90 & 1 & .90 & 1 \\
\hline Mobil Oil & 6 & .50 & 2 & .50 & 2 \\
\hline U.S. Steel & 7 & .50 & 2 & .50 & 2 \\
\hline Texaco & 8 & .50 & 2 & .50 & 2 \\
\hline IBM & 9 & .90 & 1 & .90 & 1 \\
\hline Gulf Oil & 10 & .50 & 2 & .50 & 2 \\
\hline Western Electric & 11 & 1.00 & 1 & 1.00 & 1 \\
\hline Dupont & 12 & .51 & 2 & .51 & 2 \\
\hline Swift & 13 & .15 & 3 & .15 & 3 \\
\hline Bethlehem Steel & 14 & .52 & 2 & .52 & 2 \\
\hline Shell oil & 15 & .50 & 2 & .50 & 2 \\
\hline Standard $0 i 1$ (Ind) & 16 & .47 & 2 & .47 & 2 \\
\hline Standard Oil (Cal) & 17 & .50 & 2 & .50 & 2 \\
\hline Westinghouse & 18 & .68 & 1 & .68 & $i$ \\
\hline International Harvester & 19 & .66 & 2 & .66 & 2 \\
\hline Goodyear & 20 & .38 & 2 & .38 & 2 \\
\hline Union Carbide & 21 & .57 & 2 & .58 & 2 \\
\hline Armour & 22 & .17 & 3 & .21 & 3 \\
\hline Procter and Gamble & 23 & .65 & 2 & .65 & 2 \\
\hline $\mathrm{RCA}$ & 24 & .82 & 1 & .76 & 1 \\
\hline General Telephone & 25 & .83 & 1 & .83 & 1 \\
\hline Boeing & 26 & 1.00 & 1 & 1.00 & 1 \\
\hline Kraftco & 27 & .00 & 3 & .00 & 3 \\
\hline North American Rockwe11 & 28 & .95 & 1 & .76 & 1 \\
\hline Lockheed Aircraft & 29 & .98 & 1 & .98 & 1 \\
\hline ITT & 30 & .59 & 2 & .59 & 2 \\
\hline Firestone & 31 & .40 & 2 & .40 & 2 \\
\hline General Foods & 32 & .22 & 3 & .22 & 3 \\
\hline General Dynamics & 33 & .93 & 1 & .93 & 1 \\
\hline Monsanto & 34 & .50 & 2 & .52 & 2 \\
\hline Eastman Kodak & 35 & .97 & 1 & .97 & 1 \\
\hline Phillips Petroleum & 36 & .50 & 2 & .50 & 2 \\
\hline Continental 0il & 37 & .45 & 2 & .45 & 2 \\
\hline United Aircraft & 38 & .92 & 1 & .92 & 1 \\
\hline Caterpillar Tractor & 39 & .50 & 2 & .50 & 2 \\
\hline Borden & 40 & .11 & 3 & .11 & 3 \\
\hline
\end{tabular}


Appendix B - continued

\begin{tabular}{|c|c|c|c|c|c|}
\hline Corporation & $\begin{array}{l}\text { Rank by } \\
\text { Sales } \\
1965 \\
\end{array}$ & $\begin{array}{c}\text { B } \\
1965 \\
\end{array}$ & $\begin{array}{c}\text { B } \\
\text { Classes } \\
1965 \\
\end{array}$ & $\begin{array}{c}\text { B } \\
1969 \\
\end{array}$ & $\begin{array}{c}\text { B } \\
\text { Classes } \\
1969 \\
\end{array}$ \\
\hline $\begin{array}{l}\text { Republic Steel } \\
\text { Burlington Industries } \\
\text { International Paper } \\
\text { Sinclair Oil } \\
\text { American Can }\end{array}$ & $\begin{array}{l}41 \\
42 \\
43 \\
44 \\
45\end{array}$ & $\begin{array}{l}.50 \\
.00 \\
.65 \\
.50 \\
.40\end{array}$ & $\begin{array}{l}2 \\
3 \\
2 \\
2 \\
2\end{array}$ & $\begin{array}{l}.50 \\
.00 \\
.65 \\
- \\
.40\end{array}$ & $\begin{array}{l}2 \\
3 \\
2 \\
- \\
2\end{array}$ \\
\hline $\begin{array}{l}\text { Sperry Rand } \\
\text { Union 0il } \\
\text { Continental Can } \\
\text { Uniroyal } \\
\text { Cities Service }\end{array}$ & $\begin{array}{l}46 \\
47 \\
48 \\
49 \\
50\end{array}$ & $\begin{array}{l}.80 \\
.50 \\
.26 \\
.41 \\
.50\end{array}$ & $\begin{array}{l}1 \\
2 \\
3 \\
2 \\
2\end{array}$ & $\begin{array}{l}.80 \\
.50 \\
.26 \\
.41 \\
.50\end{array}$ & $\begin{array}{l}1 \\
2 \\
3 \\
2 \\
2\end{array}$ \\
\hline $\begin{array}{l}\text { Armco Steel } \\
\text { Dow Chemical } \\
\text { Alcoa } \\
\text { Allied Chemical } \\
\text { National Steel }\end{array}$ & $\begin{array}{l}51 \\
52 \\
53 \\
54 \\
55\end{array}$ & $\begin{array}{l}.50 \\
.46 \\
.49 \\
.31 \\
.50\end{array}$ & $\begin{array}{l}2 \\
2 \\
2 \\
3 \\
2\end{array}$ & $\begin{array}{l}.48 \\
.46 \\
.49 \\
.40 \\
.50\end{array}$ & $\begin{array}{l}2 \\
2 \\
2 \\
2 \\
2\end{array}$ \\
\hline $\begin{array}{l}\text { Tenneco } \\
\text { McDonnel1 Douglas } \\
\text { Reynolds Tobacco } \\
\text { W. R. Grace } \\
\text { 3M }\end{array}$ & $\begin{array}{l}56 \\
57 \\
58 \\
59 \\
60\end{array}$ & $\begin{array}{r}.41 \\
1.00 \\
.95 \\
.30 \\
.21\end{array}$ & $\begin{array}{l}2 \\
1 \\
1 \\
3 \\
3\end{array}$ & $\begin{array}{r}.50 \\
1.00 \\
.66 \\
.27 \\
.15\end{array}$ & $\begin{array}{l}2 \\
1 \\
2 \\
3 \\
3\end{array}$ \\
\hline $\begin{array}{l}\text { Anaconda } \\
\text { Jones and Laughlin } \\
\text { American Motors } \\
\text { B. F. Goodrich } \\
\text { Singer }\end{array}$ & $\begin{array}{l}61 \\
62 \\
63 \\
64 \\
65\end{array}$ & $\begin{array}{l}.88 \\
.50 \\
.95 \\
.50 \\
.29\end{array}$ & $\begin{array}{l}1 \\
2 \\
1 \\
2 \\
3\end{array}$ & $\begin{array}{r}.88 \\
.50 \\
1.00 \\
.50 \\
.29\end{array}$ & $\begin{array}{l}1 \\
2 \\
1 \\
2 \\
3\end{array}$ \\
\hline $\begin{array}{l}\text { CPC International } \\
\text { Inland Steel } \\
\text { Ralston Purina } \\
\text { General Tire and Rubber } \\
\text { FMC }\end{array}$ & $\begin{array}{l}66 \\
67 \\
68 \\
69 \\
70\end{array}$ & $\begin{array}{l}.00 \\
.50 \\
.00 \\
.62 \\
.59\end{array}$ & $\begin{array}{l}3 \\
2 \\
3 \\
2 \\
2\end{array}$ & $\begin{array}{l}.00 \\
.50 \\
.00 \\
.62 \\
.59\end{array}$ & $\begin{array}{l}3 \\
2 \\
3 \\
2 \\
2\end{array}$ \\
\hline $\begin{array}{l}\text { Sun 0il } \\
\text { Litton } \\
\text { PPG Industries } \\
\text { Deere } \\
\text { Olin }\end{array}$ & $\begin{array}{l}71 \\
72 \\
73 \\
74 \\
75\end{array}$ & $\begin{array}{l}.52 \\
.62 \\
.72 \\
.92 \\
.50\end{array}$ & $\begin{array}{l}2 \\
2 \\
1 \\
1 \\
2\end{array}$ & $\begin{array}{l}.52 \\
.62 \\
.72 \\
.92 \\
.49\end{array}$ & $\begin{array}{l}2 \\
2 \\
1 \\
1 \\
2\end{array}$ \\
\hline $\begin{array}{l}\text { Coca-Cola } \\
\text { American Cyanamid } \\
\text { Celanese } \\
\text { Colgate-Palmolive } \\
\text { Grumman }\end{array}$ & $\begin{array}{l}76 \\
77 \\
78 \\
79 \\
80\end{array}$ & $\begin{array}{l}.90 \\
.57 \\
.50 \\
.98 \\
.98\end{array}$ & $\begin{array}{l}1 \\
2 \\
2 \\
1 \\
1\end{array}$ & $\begin{array}{l}.90 \\
.57 \\
.50 \\
.98 \\
.98\end{array}$ & $\begin{array}{l}1 \\
2 \\
2 \\
1 \\
1\end{array}$ \\
\hline
\end{tabular}


Appendix B - continued

\begin{tabular}{|c|c|c|c|c|c|}
\hline Corporation & $\begin{array}{l}\text { Rank by } \\
\text { Sales } \\
1965 \\
\end{array}$ & $\begin{array}{c}\text { B } \\
1965 \\
\end{array}$ & $\begin{array}{c}\text { B } \\
\text { Classes } \\
1965 \\
\end{array}$ & $\begin{array}{c}\text { B } \\
1969 \\
\end{array}$ & $\begin{array}{c}\text { B } \\
\text { Classes } \\
1969 \\
\end{array}$ \\
\hline Textron & 81 & .51 & 2 & .48 & 2 \\
\hline Owens-I11inois & 82 & .18 & 3 & .18 & 3 \\
\hline Wilson & 83 & .00 & 3 & - & - \\
\hline Borg-Warner & 84 & .50 & 2 & .50 & 2 \\
\hline Youngstown-Lykes & 85 & .50 & 2 & .50 & 2 \\
\hline Douglas Aircraft & 86 & 1.00 & 1 & - & - \\
\hline J. P. Stevens & 87 & .00 & 3 & .00 & 3 \\
\hline National Lead & 88 & .32 & 3 & .32 & 3 \\
\hline Bendix & 89 & .69 & 1 & .76 & 1 \\
\hline American Home Products & 90 & .63 & 2 & .53 & 2 \\
\hline Reynolds Metals & 91 & .50 & 2 & .50 & 2 \\
\hline National Cash Register & 92 & .55 & 2 & .55 & 2 \\
\hline Weyerhauser & 93 & .50 & 2 & .50 & 2 \\
\hline Allis-Chalmers & 94 & .72 & 1 & .72 & 1 \\
\hline Campbell Soup & 95 & .50 & 2 & .50 & 2 \\
\hline Crown Zellerbach & 96 & .37 & 2 & .37 & 2 \\
\hline American Brands & 97 & 1.00 & 1 & .84 & 1 \\
\hline Tidewater 0il & 98 & .50 & 2 & - & - \\
\hline Genesco & 99 & .00 & 3 & .00 & 3 \\
\hline Eaton Yale and Towne & 100 & .56 & 2 & .56 & 2 \\
\hline Honeywe11 & 101 & 1.00 & 1 & 1.00 & 1 \\
\hline Morrell & 102 & .00 & 3 & - & - \\
\hline Atlantic Richfield & 103 & .50 & 2 & .50 & 2 \\
\hline Beatrice Foods & 104 & .10 & 3 & .10 & 3 \\
\hline Signal Companies & 105 & .50 & 2 & .58 & 2 \\
\hline Kennecott Copper & 106 & .95 & 1 & .95 & 1 \\
\hline TRW & 107 & .60 & 2 & .60 & 2 \\
\hline Pullman & 108 & .10 & 3 & .10 & 3 \\
\hline White Motor & 109 & .58 & 2 & .58 & 2 \\
\hline Standard Brands & 110 & .10 & 3 & .10 & 3 \\
\hline St. Regis Paper & 111 & .28 & 3 & .44 & 2 \\
\hline Whirlpool & 112 & .50 & 2 & .50 & 2 \\
\hline National Biscuit & 113 & .00 & B & .00 & 3 \\
\hline American Smelting and & & & & & \\
\hline Refining & 114 & .83 & 1 & .83 & 1 \\
\hline Martin Marietta & 115 & .75 & 1 & .78 & 1 \\
\hline Standard Oil (Ohio) & 116 & .50 & 2 & .50 & 2 \\
\hline Kimber1y-Clark & 117 & .50 & 2 & .50 & 2 \\
\hline Kaiser Aluminum and & & & & & \\
\hline Chemical & 118 & $.50^{\circ}$ & 2 & .50 & 2 \\
\hline Georgia Pacific & 119 & .55 & 2 & .54 . & 2 \\
\hline United Merchants and & & & & & \\
\hline Manufacturers & 120 & .04 & 3 & .04 & 3 \\
\hline
\end{tabular}


Appendix B - continued

\begin{tabular}{|c|c|c|c|c|c|}
\hline Corporation & $\begin{array}{l}\text { Rank by } \\
\text { Sales } \\
1965 \\
\end{array}$ & $\begin{array}{c}\text { B } \\
1965 \\
\end{array}$ & $\begin{array}{c}\text { B } \\
\text { Classes } \\
1965 \\
\end{array}$ & $\begin{array}{c}\text { B. } \\
1969 \\
\end{array}$ & $\begin{array}{c}\text { B } \\
\text { Classes } \\
1969 \\
\end{array}$ \\
\hline General Mills & 121 & .48 & 2 & .46 & 2 \\
\hline American Standard & 122 & .26 & 3 & .26 & 3 \\
\hline Marathon 0il & 123 & .50 & 2 & .50 & 2 \\
\hline Mead & 124 & .50 & 2 & .34 & 2 \\
\hline Pfizer & 125 & .73 & 1 & .73 & 1 \\
\hline Kaiser Industries & 126 & .49 & 2 & - & - \\
\hline Carnation & 127 & .00 & 3 & .00 & 3 \\
\hline Hercules & 128 & .38 & 2 & .34 & 2 \\
\hline Continental Baking & 129 & .50 & 2 & - & - \\
\hline H. J. Heinz & 130 & .15 & 3 & .15 & 3 \\
\hline Motorola & 131 & .50 & 2 & .50 & 2 \\
\hline Pepsico & 132 & .78 & 1 & .78 & 1 \\
\hline Rockwell -Standard & 133 & .00 & 3 & - & - \\
\hline Ogden & 134 & .42 & 2 & .42 & 2 \\
\hline National Distillers & & & & & \\
\hline and Chemical & 135 & .75 & 1 & .74 & 1 \\
\hline Raytheon & 136 & .50 & 2 & .50 & 2 \\
\hline Sunray DX & 137 & .50 & 2 & - & - \\
\hline Babcock and Wilcox & 138 & .75 & 1 & .75 & 1 \\
\hline Johns-Manville & 139 & .00 & 3 & .00 & 3 \\
\hline Hygrade Food Products & 140 & .00 & 3 & .00 & 3 \\
\hline American Metal Climax & 141 & .45 & 2 & .45 & 2 \\
\hline Zenith & 142 & .50 & 2 & .50 & 2 \\
\hline Central Soya & 143 & .00 & 3 & .00 & 3 \\
\hline Quaker Oats & 144 & .65 & 2 & .65 & 2 \\
\hline Scott Paper & 145 & .45 & 2 & .45 & 2 \\
\hline Phelps Dodge & 146 & .98 & 1 & .98 & 1 \\
\hline Philip Morris & 147 & 1.00 & 1 & .98 & 1 \\
\hline Burroughs & 148 & .89 & 1 & .89 & 1 \\
\hline Lever Brothers & 149 & - & - & - & - \\
\hline McGraw-Edison & 150 & .50 & 2 & .50 & 2 \\
\hline Time & 151 & .42 & 2 & .42 & 2 \\
\hline U.S. P1ywood-Champion & & & & & \\
\hline Papers & 152 & .50 & 2 & .44 & 2 \\
\hline Ashland Oil & 153 & .50 & 2 & .50 & 2 \\
\hline Hunt Foods & 154 & .05 & 3 & - & - \\
\hline Budd & 155 & .40 & 2 & .40 & 2 \\
\hline Pillsbury & 156 & .11 & 3 & .11 & 3 \\
\hline Avco & 157 & .38 & 2 & .41 & 2 \\
\hline Hormel & 158 & .00 & 3 & .00 & 3 \\
\hline Inger so11-Rand & 159 & .54 & 2 & .54 & 2 \\
\hline Texas Instruments & 160 & .50 & 2 & .50 & 2 \\
\hline
\end{tabular}


Appendix B - continued

\begin{tabular}{|c|c|c|c|c|c|}
\hline Corporation & $\begin{array}{l}\text { Rank by } \\
\text { Sales } \\
1965\end{array}$ & $\begin{array}{c}\text { B } \\
1965 \\
\end{array}$ & $\begin{array}{c}\text { B } \\
\text { Classes } \\
1965 \\
\end{array}$ & $\begin{array}{c}\text { B } \\
1969 \\
\end{array}$ & $\begin{array}{c}\text { B } \\
\text { Classes } \\
1969 \\
\end{array}$ \\
\hline $\begin{array}{l}\text { Johnson and Johnson } \\
\text { American Sugar } \\
\text { Del Monte } \\
\text { Champion Papers } \\
\text { Anheuser-Busch }\end{array}$ & $\begin{array}{l}161 \\
162 \\
163 \\
164 \\
165\end{array}$ & $\begin{array}{l}.00 \\
.50 \\
.00 \\
.50 \\
.50\end{array}$ & $\begin{array}{l}3 \\
2 \\
3 \\
2 \\
2\end{array}$ & $\begin{array}{l}.00 \\
.50 \\
.00 \\
- \\
.50\end{array}$ & $\begin{array}{l}3 \\
2 \\
3 \\
- \\
2\end{array}$ \\
\hline $\begin{array}{l}\text { Boise Cascade } \\
\text { Otis Elevator } \\
\text { Container Corp. of } \\
\quad \text { America } \\
\text { Combustion Engring. } \\
\text { Dana }\end{array}$ & $\begin{array}{l}168 \\
169 \\
170\end{array}$ & $\begin{array}{l}.00 \\
.50 \\
.50\end{array}$ & $\begin{array}{l}3 \\
2 \\
2\end{array}$ & $\begin{array}{l}- \\
.50 \\
.50\end{array}$ & $\begin{array}{l}- \\
2 \\
2\end{array}$ \\
\hline $\begin{array}{l}\text { Xerox } \\
\text { Clark Equipment } \\
\text { Interco } \\
\text { Bristol-Myers } \\
\text { Fruehauf }\end{array}$ & $\begin{array}{l}171 \\
172 \\
173 \\
174 \\
175\end{array}$ & $\begin{array}{r}1.00 \\
.45 \\
.00 \\
.58 \\
.00\end{array}$ & $\begin{array}{l}1 \\
2 \\
3 \\
2 \\
3\end{array}$ & $\begin{array}{r}1.00 \\
.45 \\
.00 \\
.68 \\
.00\end{array}$ & $\begin{array}{l}1 \\
2 \\
3 \\
1 \\
3\end{array}$ \\
\hline $\begin{array}{l}\text { AMF } \\
\text { Warner-Lambert } \\
\text { IPL } \\
\text { Air Reduction } \\
\text { Timken }\end{array}$ & $\begin{array}{l}176 \\
177 \\
178 \\
179 \\
180\end{array}$ & $\begin{array}{l}.40 \\
.78 \\
.00 \\
.52 \\
.00\end{array}$ & $\begin{array}{l}2 \\
1 \\
3 \\
2 \\
3\end{array}$ & $\begin{array}{l}.40 \\
.78 \\
- \\
.54 \\
.00\end{array}$ & $\begin{array}{l}2 \\
1 \\
- \\
2 \\
3\end{array}$ \\
\hline $\begin{array}{l}\text { Armstrong Cork } \\
\text { Koppers } \\
\text { Crane } \\
\text { Mack Trucks } \\
\text { Kellogg }\end{array}$ & $\begin{array}{l}181 \\
182 \\
183 \\
184 \\
185\end{array}$ & $\begin{array}{r}.45 \\
.50 \\
.25 \\
.50 \\
1.00\end{array}$ & $\begin{array}{l}2 \\
2 \\
3 \\
2 \\
1\end{array}$ & $\begin{array}{l}.45 \\
.50 \\
.25 \\
- \\
1.00\end{array}$ & $\begin{array}{l}2 \\
2 \\
3 \\
- \\
1\end{array}$ \\
\hline $\begin{array}{l}\text { Agway } \\
\text { Dart Industries } \\
\text { A. 0. Smith } \\
\text { Foremost Dairies } \\
\text { Dresser Industries }\end{array}$ & $\begin{array}{l}186 \\
187 \\
188 \\
189 \\
190\end{array}$ & $\begin{array}{l}- \\
.23 \\
.50 \\
.00 \\
.50\end{array}$ & $\begin{array}{l}- \\
3 \\
2 \\
3 \\
2\end{array}$ & $\begin{array}{l}- \\
.23 \\
.50 \\
- \\
.50\end{array}$ & $\begin{array}{l}- \\
3 \\
2 \\
- \\
2\end{array}$ \\
\hline $\begin{array}{l}\text { Seagram and Sons } \\
\text { Avon } \\
\text { Carrier } \\
\text { Amerada Hess } \\
\text { Rohm and Haas }\end{array}$ & $\begin{array}{l}191 \\
192 \\
193 \\
194 \\
195\end{array}$ & $\begin{array}{r}1.00 \\
.50 \\
.50 \\
.50 \\
.52\end{array}$ & $\begin{array}{l}1 \\
2 \\
2 \\
2 \\
2\end{array}$ & $\begin{array}{r}1.00 \\
.50 \\
.50 \\
.50 \\
.52\end{array}$ & $\begin{array}{l}1 \\
2 \\
2 \\
2 \\
2\end{array}$ \\
\hline $\begin{array}{l}\text { Pet } \\
\text { Sherwin-Williams } \\
\text { Diamond International } \\
\text { Worthington } \\
\text { General American } \\
\quad \text { Transportation }\end{array}$ & $\begin{array}{l}196 \\
197 \\
198 \\
199\end{array}$ & $\begin{array}{l}.00 \\
.45 \\
.50 \\
.70\end{array}$ & $\begin{array}{l}3 \\
2 \\
2 \\
1\end{array}$ & $\begin{array}{l}.06 \\
.45 \\
.48 \\
-\end{array}$ & $\begin{array}{l}3 \\
2 \\
2 \\
-\end{array}$ \\
\hline
\end{tabular}


Appendix B - continued

\begin{tabular}{|c|c|c|c|c|c|}
\hline Corporation & $\begin{array}{l}\text { Rank by } \\
\text { Sales } \\
1965 \\
\end{array}$ & $\begin{array}{c}\text { B } \\
1965 \\
\end{array}$ & $\begin{array}{c}\text { B } \\
\text { Classes } \\
1965 \\
\end{array}$ & $\begin{array}{c}\text { B } \\
1969 \\
\end{array}$ & $\begin{array}{c}\text { B } \\
\text { Classes } \\
1969 \\
\end{array}$ \\
\hline Corning Glass Works & 201 & .50 & 2 & .50 & 2 \\
\hline Northrop & 202 & .87 & 1 & .87 & 1 \\
\hline Gillette & 203 & .55 & 2 & .55 & 2 \\
\hline LTV & 204 & .46 & 2 & .46 & 2 \\
\hline Allegheny-Ludlum & 205 & .50 & 2 & .50 & 2 \\
\hline Owens-Corning Fiberglass & 206 & .50 & 2 & .50 & 2 \\
\hline Magnovox & 207 & .42 & 2 & .42 & 2 \\
\hline Merck & 208 & .78 & 1 & .78 & 1 \\
\hline Cerro & 209 & .50 & 2 & .50 & 2 \\
\hline Stauffer Chemical & 210 & .50 & 2 & .50 & 2 \\
\hline Westvaco & 211 & .75 & 1 & .75 & 1 \\
\hline Archer-Daniels-Midland & 212 & .03 & 3 & .00 & 3 \\
\hline Kerr-McGee & 213 & .50 & 2 & .50 & 2 \\
\hline Int'1. Multifoods & 214 & .00 & 3 & .00 & 3 \\
\hline West Point-Pepperel1 & 215 & - & - & .00 & 3 \\
\hline E1i Lilly & 216 & 1.00 & 1 & 1.00 & 1 \\
\hline Consolidated Coal & 217 & .00 & 3 & - & - \\
\hline Brunswick & 218 & .15 & 3 & .15 & 3 \\
\hline Richfield Oil & 219 & .50 & 2 & - & - \\
\hline Crucible Steel & 220 & .50 & 2 & - & - \\
\hline Cudahy & 221 & .02 & 3 & .02 & 3 \\
\hline Ethyl & 222 & .50 & 2 & .50 & 2 \\
\hline Kaiser Steel & 223 & .50 & 2 & .50 & 2 \\
\hline Oscar Mayer & 224 & .00 & 3 & .00 & 3 \\
\hline U.S. Gypsum & 225 & .09 & 3 & .09 & 3 \\
\hline ACF Industries & 226 & .00 & 3 & .00 & 3 \\
\hline Glidden & 227 & .29 & 3 & - & - \\
\hline Sterling Drug & 228 & .92 & 1 & .84 & 1 \\
\hline General Cable & 229 & .50 & 2 & .50 & 2 \\
\hline Libby McNeill and Libby & 230 & .08 & 3 & .08 & 3 \\
\hline Admiral & 231 & .50 & 2 & .50 & 2 \\
\hline Essex International & 232 & - & - & .53 & 2 \\
\hline Grinnel1 & 233 & .00 & 3 & - & - \\
\hline Midland-Ross & 234 & .50 & 2 & .50 & 2 \\
\hline Land O'Lakes Creameries & 235 & - & - & - & - \\
\hline Pacific Car and Foundry & 236 & .05 & 3 & .05 & 3 \\
\hline Liggett and Myers & 237 & 1.000 & 1 & .62 & 2 \\
\hline P. Lorillard & 238 & 1.00 & 1 & - & - \\
\hline Lowenstein and Sons & 239 & .00 & 3 & .00 & 3 \\
\hline Revere Copper and Brass & 240 & .75 & 1 & .75 & 3 \\
\hline
\end{tabular}


Appendix B - continued

\begin{tabular}{|c|c|c|c|c|c|}
\hline Corporation & $\begin{array}{l}\text { ank by } \\
\text { ales } \\
965 \\
\end{array}$ & $\begin{array}{c}\text { B } \\
1965 \\
\end{array}$ & $\begin{array}{c}\text { B } \\
\text { Classes } \\
1965 \\
\end{array}$ & $\begin{array}{c}\text { B } \\
1969 \\
\end{array}$ & $\begin{array}{c}\text { B } \\
\text { Classes } \\
1969 \\
\end{array}$ \\
\hline $\begin{array}{l}\text { Philadelphia and Reading } \\
\text { Flintkote } \\
\text { Union Camp } \\
\text { Collins Radio } \\
\text { Cummins Engine }\end{array}$ & $\begin{array}{l}241 \\
242 \\
243 \\
244 \\
245\end{array}$ & $\begin{array}{r}.00 \\
.11 \\
.28 \\
1.00 \\
.50\end{array}$ & $\begin{array}{l}3 \\
3 \\
3 \\
1 \\
2\end{array}$ & $\begin{array}{r}- \\
.10 \\
.28 \\
1.00 \\
.50\end{array}$ & $\begin{array}{l}- \\
3 \\
3 \\
1 \\
2\end{array}$ \\
\hline $\begin{array}{l}\text { H. K. Porter } \\
\text { Cannon Mills } \\
\text { Libbey-Owens-Ford } \\
\text { Rath Packing } \\
\text { Newport News Ship- } \\
\quad \text { building }\end{array}$ & $\begin{array}{l}246 \\
247 \\
248 \\
249 \\
\\
250\end{array}$ & $\begin{array}{r}.49 \\
.00 \\
1.00 \\
.00 \\
.95\end{array}$ & $\begin{array}{l}2 \\
3 \\
1 \\
3\end{array}$ & $\begin{array}{r}.49 \\
.00 \\
1.00 \\
.00\end{array}$ & $\begin{array}{l}2 \\
3 \\
1 \\
3\end{array}$ \\
\hline $\begin{array}{l}\text { Skelly 0il } \\
\text { Westinghouse Air Brakes } \\
\text { J. I. Case } \\
\text { Norton } \\
\text { Wheeling-Pittsburgh Steel }\end{array}$ & $\begin{array}{l}251 \\
252 \\
253 \\
254 \\
255\end{array}$ & $\begin{array}{r}.50 \\
.40 \\
1.00 \\
.08 \\
.50\end{array}$ & $\begin{array}{l}2 \\
2 \\
1 \\
3 \\
2\end{array}$ & $\begin{array}{r}.50 \\
- \\
1.00 \\
.08 \\
.50\end{array}$ & $\begin{array}{l}2 \\
- \\
1 \\
3 \\
3\end{array}$ \\
\hline $\begin{array}{l}\text { Addressograph- } \\
\quad \text { Multigraph } \\
\text { Scovill Manufacturing } \\
\text { Brown Shoe } \\
\text { Consumers Co-op Assn. } \\
\text { Inmont }\end{array}$ & $\begin{array}{l}256 \\
257 \\
258 \\
259 \\
260\end{array}$ & $\begin{array}{l}.50 \\
.05 \\
.00 \\
. \\
.14\end{array}$ & $\begin{array}{l}2 \\
3 \\
3 \\
- \\
3\end{array}$ & $\begin{array}{l}.50 \\
.05 \\
.00 \\
- \\
.14\end{array}$ & $\begin{array}{l}2 \\
3 \\
3 \\
- \\
3\end{array}$ \\
\hline $\begin{array}{l}\text { Int'1. Minerals and } \\
\quad \text { Chemicals } \\
\text { Interlake } \\
\text { Abex } \\
\text { National Gypsum } \\
\text { North American Philips }\end{array}$ & $\begin{array}{l}261 \\
262 \\
263 \\
264 \\
265\end{array}$ & $\begin{array}{r}.46 \\
.48 \\
.00 \\
.36 \\
1.00\end{array}$ & $\begin{array}{l}2 \\
2 \\
3 \\
2 \\
1\end{array}$ & $\begin{array}{c}.46 \\
.45 \\
- \\
.36 \\
1.00\end{array}$ & $\begin{array}{l}2 \\
2 \\
- \\
2 \\
1\end{array}$ \\
\hline $\begin{array}{l}\text { Crown Cork and Seal } \\
\text { American Bakeries } \\
\text { Cluett, Peabody } \\
\text { Eltra } \\
\text { Cone Mills }\end{array}$ & $\begin{array}{l}266 \\
267 \\
268 \\
269 \\
270\end{array}$ & $\begin{array}{l}.40 \\
.50 \\
.00 \\
.48 \\
.00\end{array}$ & $\begin{array}{l}2 \\
2 \\
3 \\
2 \\
3\end{array}$ & $\begin{array}{l}.40 \\
.50 \\
.00 \\
.48 \\
.00\end{array}$ & $\begin{array}{l}2 \\
2 \\
3 \\
2 \\
3\end{array}$ \\
\hline $\begin{array}{l}\text { Emerson Electric } \\
\text { Springs Mills } \\
\text { Tecumseh Products } \\
\text { Joseph Schlitz Brewing } \\
\text { Evans Products }\end{array}$ & $\begin{array}{l}271 \\
272 \\
273 \\
274 \\
275\end{array}$ & $\begin{array}{l}.70 \\
- \\
.08 \\
.50 \\
.00\end{array}$ & $\begin{array}{l}1 \\
- \\
3 \\
2 \\
3\end{array}$ & $\begin{array}{l}.70 \\
.00 \\
.08 \\
.50 \\
.18\end{array}$ & $\begin{array}{l}1 \\
3 \\
3 \\
2 \\
3\end{array}$ \\
\hline $\begin{array}{l}\text { Dan River } \\
\text { Revlon } \\
\text { Hooker Chemical }\end{array}$ & $\begin{array}{l}276 \\
277 \\
278\end{array}$ & $\begin{array}{l}.00 \\
.50 \\
.50\end{array}$ & $\begin{array}{l}3 \\
2 \\
2\end{array}$ & $\begin{array}{l}.00 \\
.60 \\
-\end{array}$ & $\begin{array}{l}3 \\
2 \\
-\end{array}$ \\
\hline $\begin{array}{l}\text { Hoover } \\
\text { Smith Kline and French }\end{array}$ & $\begin{array}{l}279 \\
280\end{array}$ & $\begin{array}{l}.10 \\
.86\end{array}$ & $\begin{array}{l}3 \\
1\end{array}$ & $\begin{array}{l}.10 \\
.86\end{array}$ & $\begin{array}{l}3 \\
1\end{array}$ \\
\hline
\end{tabular}


Appendix B - continued

\begin{tabular}{|c|c|c|c|c|c|}
\hline Corporation & $\begin{array}{l}\text { Rank by } \\
\text { Sales } \\
1965 \\
\end{array}$ & $\begin{array}{c}\text { B } \\
1965 \\
\end{array}$ & $\begin{array}{c}\text { B } \\
\text { Classes } \\
1965 \\
\end{array}$ & $\begin{array}{c}\text { B } \\
1969 \\
\end{array}$ & $\begin{array}{c}\text { B } \\
\text { Classes } \\
1969 \\
\end{array}$ \\
\hline $\begin{array}{l}\text { Foster Wheeler } \\
\text { Upjohn } \\
\text { General Precision } \\
\text { Kayser-Roth } \\
\text { Kelsey-Hayes }\end{array}$ & $\begin{array}{l}281 \\
282 \\
283 \\
284 \\
285\end{array}$ & $\begin{array}{l}.50 \\
.86 \\
.50 \\
.00 \\
.00\end{array}$ & $\begin{array}{l}2 \\
1 \\
2 \\
3 \\
3\end{array}$ & $\begin{array}{l}.50 \\
.86 \\
- \\
.00 \\
.00\end{array}$ & $\begin{array}{l}2 \\
1 \\
- \\
3 \\
3\end{array}$ \\
\hline $\begin{array}{l}\text { Abott Laboratories } \\
\text { Englehard Industries } \\
\text { Ryan Aeronautical } \\
\text { Times-Mirror } \\
\text { Di Giorgio }\end{array}$ & $\begin{array}{l}286 \\
287 \\
288 \\
289 \\
290\end{array}$ & $\begin{array}{l}.51 \\
.95 \\
.95 \\
.55 \\
.00\end{array}$ & $\begin{array}{l}2 \\
1 \\
1 \\
2 \\
3\end{array}$ & $\begin{array}{l}.51 \\
.95 \\
. \\
.55 \\
.05\end{array}$ & $\begin{array}{l}2 \\
1 \\
- \\
2 \\
3\end{array}$ \\
\hline $\begin{array}{l}\text { CFI Steel } \\
\text { Sunbeam } \\
\text { Campbell Taggert } \\
\text { USM } \\
\text { R. R. Donnelley and Sons }\end{array}$ & $\begin{array}{l}291 \\
292 \\
293 \\
294 \\
295\end{array}$ & $\begin{array}{l}.50 \\
.10 \\
.50 \\
.39 \\
.00\end{array}$ & $\begin{array}{l}2 \\
3 \\
2 \\
2 \\
3\end{array}$ & $\begin{array}{l}.50 \\
.10 \\
.50 \\
.39 \\
.00\end{array}$ & $\begin{array}{l}2 \\
3 \\
2 \\
2 \\
3\end{array}$ \\
\hline $\begin{array}{l}\text { Parke Davis } \\
\text { Stokely-Van Camp } \\
\text { A. E. Staley Mfg. } \\
\text { Schenley Industries } \\
\text { McLouth Steel }\end{array}$ & $\begin{array}{l}296 \\
297 \\
298 \\
299 \\
300\end{array}$ & $\begin{array}{r}.70 \\
.00 \\
.00 \\
1.00 \\
.50\end{array}$ & $\begin{array}{l}1 \\
3 \\
3 \\
1 \\
2\end{array}$ & $\begin{array}{r}.70 \\
.00 \\
.00 \\
1.00 \\
.50\end{array}$ & $\begin{array}{l}1 \\
3 \\
3 \\
1 \\
2\end{array}$ \\
\hline $\begin{array}{l}\text { McGraw-Hill } \\
\text { GAF } \\
\text { Federal Mogul } \\
\text { Richardson-Merrel1 } \\
\text { Link-Belt }\end{array}$ & $\begin{array}{l}301 \\
302 \\
303 \\
304 \\
305\end{array}$ & $\begin{array}{l}.18 \\
.62 \\
.00 \\
.95 \\
.50\end{array}$ & $\begin{array}{l}3 \\
2 \\
3 \\
1 \\
2\end{array}$ & $\begin{array}{l}.18 \\
.62 \\
.00 \\
.95 \\
-\end{array}$ & $\begin{array}{l}3 \\
2 \\
3 \\
1 \\
-\end{array}$ \\
\hline $\begin{array}{l}\text { Chemetron } \\
\text { Hershey Foods } \\
\text { Amerada Petroleum } \\
\text { Diamond Shamrock } \\
\text { Peabody Coal }\end{array}$ & $\begin{array}{l}306 \\
307 \\
308 \\
309 \\
310\end{array}$ & $\begin{array}{l}.50 \\
.50 \\
.50 \\
.50 \\
.00\end{array}$ & $\begin{array}{l}2 \\
2 \\
2 \\
2 \\
3\end{array}$ & $\begin{array}{l}.50 \\
.50 \\
- \\
.50 \\
-\end{array}$ & $\begin{array}{l}2 \\
2 \\
- \\
2 \\
-\end{array}$ \\
\hline $\begin{array}{l}\text { Ex-Cel1-0 } \\
\text { Beech-Nut Life Savers } \\
\text { Potlatch Forests } \\
\text { Carborundum } \\
\text { Bemis }\end{array}$ & $\begin{array}{l}311 \\
312 \\
313 \\
314 \\
315\end{array}$ & $\begin{array}{l}.44 \\
.50 \\
.50 \\
.25 \\
.32\end{array}$ & $\begin{array}{l}2 \\
2 \\
2 \\
3 \\
3\end{array}$ & $\begin{array}{l}.52 \\
- \\
.50 \\
.25 \\
.32\end{array}$ & $\begin{array}{l}2 \\
- \\
2 \\
3 \\
3\end{array}$ \\
\hline $\begin{array}{l}\text { Polaroid } \\
\text { Sunshine Biscuits } \\
\text { Cincinnati Milacron } \\
\text { ESB } \\
\text { Colt Industries }\end{array}$ & $\begin{array}{l}316 \\
317 \\
318 \\
319 \\
320\end{array}$ & $\begin{array}{l}.95 \\
.00 \\
.26 \\
.62 \\
.62\end{array}$ & $\begin{array}{l}1 \\
3 \\
3 \\
2 \\
2\end{array}$ & $\begin{array}{l}.95 \\
- \\
.26 \\
.62 \\
.62\end{array}$ & $\begin{array}{l}1 \\
- \\
3 \\
2 \\
2\end{array}$ \\
\hline
\end{tabular}


Appendix B - continued

\begin{tabular}{|c|c|c|c|c|c|}
\hline Corporation & $\begin{array}{l}\text { Rank by } \\
\text { Sales } \\
1965 \\
\end{array}$ & $\begin{array}{c}\text { B } \\
1965 \\
\end{array}$ & $\begin{array}{c}\text { Classes } \\
1965 \\
\end{array}$ & $\begin{array}{c}\text { B } \\
1969 \\
\end{array}$ & $\begin{array}{c}\text { B } \\
\text { Classes } \\
1969 \\
\end{array}$ \\
\hline Lone Star Cement & 321 & .50 & 2 & .50 & 2 \\
\hline Gerber & 322 & .50 & 2 & .50 & 2 \\
\hline Cotton Producers Assn. & 323 & - & - & - & - \\
\hline American Enka & 324 & .50 & 2 & .50 & 2 \\
\hline Studebaker & 325 & .20 & 3 & - & - \\
\hline Cutler-Hammer & 326 & .69 & 1 & .69 & 1 \\
\hline Lear Siegler & 327 & .44 & 2 & .44 & 2 \\
\hline Stanley Warner & 328 & .49 & 2 & - & - \\
\hline Fairmont Foods & 329 & .00 & 3 & .00 & 3 \\
\hline Indian Head & 330 & .02 & 3 & .01 & 3 \\
\hline Emhart & 331 & .34 & 2 & .34 & 2 \\
\hline Amsted Industries & 332 & .20 & 3 & .40 & 2 \\
\hline Eastern Gas and Fuel & 333 & .22 & 3 & .22 & 3 \\
\hline Hupp & 334 & .42 & 2 & - & - \\
\hline Rockwell Manufacturing & 335 & .01 & 3 & .01 & 3 \\
\hline Sharon Steel & 336 & .50 & 2 & .50 & 2 \\
\hline Bel1 and Howell & 337 & .60 & 2 & .60 & 2 \\
\hline Iowa Beef Packers & 338 & .00 & 3 & .00 & 3 \\
\hline Blaw-Knox & 339 & .50 & 2 & - & - \\
\hline Pittsburgh Steel & 340 & .50 & 2 & - & - \\
\hline Gulf and Western & 341 & .07 & 3 & .25 & 3 \\
\hline McCa11 & 342 & .25 & 3 & - & - \\
\hline Fairchild Camera & 343 & .50 & 2 & .50 & 2 \\
\hline Outboard Marine & 344 & .50 & 2 & .50 & 2 \\
\hline Mohasco Industries & 345 & .12 & 3 & .12 & 3 \\
\hline Pabst Brewing & 346 & .50 & 2 & .50 & 2 \\
\hline Square $\mathrm{D}$ & 347 & 1.00 & 1 & 1.00 & 1 \\
\hline Castle and Cooke & 348 & .05 & 3 & .05 & 3 \\
\hline Chicago Bridge and Iron & 349 & .00 & 3 & .00 & 3 \\
\hline Purex & 350 & .35 & 2 & .45 & 2 \\
\hline Thiokol Chemical & 351 & .60 & 2 & .60 & 2 \\
\hline Cyclops & 352 & .50 & 2 & .50 & 2 \\
\hline Interstate Brands & 353 & .50 & 2 & .48 & 2 \\
\hline Murphy Oil & 354 & .50 & 2 & .50 & 2 \\
\hline Simmons & 355 & .00 & 3 & .00 & 3 \\
\hline Ward Foods & 356 & .26 & 3 & .26 & 3 \\
\hline Anchor Hocking & 357 & .00 & 3 & .00 & 3 \\
\hline Rayonier & 358 & .90 & 1 & - & - \\
\hline American Chain and Cable & 359 & .40 & 2 & .40 & 2 \\
\hline Granite City Steel & 360 & .42 & 2 & .42 & 2 \\
\hline
\end{tabular}


Appendix B - continued

\begin{tabular}{|c|c|c|c|c|c|}
\hline Corporation & $\begin{array}{l}\text { Rank by } \\
\text { Sales } \\
1965\end{array}$ & $\begin{array}{c}\text { B } \\
1965 \\
\end{array}$ & $\begin{array}{c}\text { Classes } \\
1965 \\
\end{array}$ & $\begin{array}{c}\text { B } \\
1969 \\
\end{array}$ & $\begin{array}{c}\text { B } \\
\text { Classes } \\
1969 \\
\end{array}$ \\
\hline Thomas J. Lipton & 361 & - & - & - & - \\
\hline Stanley Works & 362 & .00 & 3 & .00 & 3 \\
\hline Hart Schaffner and Mara & 363 & .00 & 3 & .00 & 3 \\
\hline Eagle-Picher & 364 & .40 & 2 & .40 & 2 \\
\hline Hewlett-Packard & 365 & 1.00 & 1 & 1.00 & 1 \\
\hline Kenda11 & 366 & .08 & 3 & .08 & 3 \\
\hline Trane & 367 & .50 & 2 & .50 & 2 \\
\hline Hammermil1 Paper & 368 & .75 & 1 & .75 & 1 \\
\hline Kern County Land & 369 & .00 & 3 & - & - \\
\hline Harsco & 370 & .00 & 3 & .00 & 3 \\
\hline Control Data & 371 & 1.00 & 1 & 1.00 & 1 \\
\hline Beaunit & 372 & .17 & 3 & .17 & 3 \\
\hline Fieldcrest Mills & 373 & .00 & 3 & .00 & 3 \\
\hline Jim Walter & 374 & .02 & 3 & .02 & 3 \\
\hline Pocolet Industries & 375 & .00 & 3 & - & - \\
\hline Rohr & 376 & .91 & 1 & .91 & 1 \\
\hline General Host & 377 & .50 & 2 & .48 & 2 \\
\hline Pennwalt & 378 & .53 & 2 & .53 & 2 \\
\hline Houdaille & 379 & .33 & 3 & .33 & 3 \\
\hline U.S. Pipe and Foundry & 380 & .50 & 2 & - & - \\
\hline American Petrofina & 381 & .50 & 2 & .50 & 2 \\
\hline Keystone Consolidated & 382 & .35 & 2 & .35 & 2 \\
\hline Jonathan Logan & 383 & .00 & 3 & .00 & 3 \\
\hline National Can & 384 & .50 & 2 & .47 & 2 \\
\hline Ampex & 385 & .58 & 2 & .58 & 2 \\
\hline Ruberoid & 386 & .10 & 3 & - & - \\
\hline Falstaff Brewing & 387 & .50 & 2 & .50 & 2 \\
\hline Stewart-Warner & 388 & .45 & 2 & .45 & 2 \\
\hline Universal American & 389 & .00 & 3 & - & - \\
\hline SCM & 390 & .35 & 2 & .35 & 2 \\
\hline Joy Manufacturing & 391 & .50 & 2 & .50 & 2 \\
\hline ITE Imperial & 392 & 1.00 & 1 & 1.00 & 1 \\
\hline Standard Packaging & 393 & .60 & 2 & .60 & 2 \\
\hline Cessna Aircraft & 394 & 1.00 & 1 & 1.00 & 1 \\
\hline Curtiss-Wright & 395 & .70 & 1 & .70 & 1 \\
\hline Hanna Mining & 396 & 1.00 & 1 & 1.00 & 1 \\
\hline Allied Mills & 397 & .00 & 3 & .00 & 3 \\
\hline Armstrong Rubber & 398 & .50 & 2 & .50 & 2 \\
\hline Koehring & 399 & .50 & 2 & .50 & 2 \\
\hline Vulcan Materials & 400 & .50 & 2 & .50 & 2 \\
\hline
\end{tabular}


Appendix B - continued

\begin{tabular}{|c|c|c|c|c|c|}
\hline Corporation & $\begin{array}{l}\text { Rank by } \\
\text { Sales } \\
1965\end{array}$ & $\begin{array}{c}\text { B } \\
1965 \\
\end{array}$ & $\begin{array}{c}\text { Classes } \\
1965 \\
\end{array}$ & $\begin{array}{c}\text { B } \\
1969 \\
\end{array}$ & $\begin{array}{c}\text { B } \\
\text { Classes } \\
1969 \\
\end{array}$ \\
\hline Witco Chemical & 401 & .50 & 2 & .50 & 2 \\
\hline Consolidated Cigar & 402 & .50 & 2 & - & - \\
\hline Arvin Industries & 403 & .22 & 3 & .22 & 3 \\
\hline New York Times & 404 & .97 & 1 & .97 & 1 \\
\hline Rex Chainbelt & 405 & .43 & 2 & .43 & 2 \\
\hline Ideal Basic Industries & 406 & .50 & 2 & .50 & 2 \\
\hline Inland Container & 407 & .15 & 3 & .15 & 3 \\
\hline Chesebrough-Pond's & 408 & .53 & 2 & .53 & 2 \\
\hline Western Publishing & 409 & .00 & 3 & .00 & 3 \\
\hline Keebler & 410 & .00 & 3 & .00 & 3 \\
\hline Miles Laboratories & 411 & .77 & 1 & .77 & 1 \\
\hline Lukens Steel & 412 & .50 & 2 & .50 & 2 \\
\hline Riegel Paper & 413 & .48 & 2 & .48 & 2 \\
\hline Cowles Communications & 414 & .67 & 1 & .67 & 1 \\
\hline St.Joe Minerals & 415 & .50 & 2 & .50 & 2 \\
\hline Kellwood & 416 & .00 & 3 & .00 & 3 \\
\hline Clark Oil & 417 & .50 & 2 & .50 & 2 \\
\hline Rheem Manufacturing & 418 & .18 & 3 & - & - \\
\hline Calumet and Hecla & 419 & .55 & 2 & - & - \\
\hline Grolier & 420 & .00 & 3 & .00 & 3 \\
\hline Sybron & 421 & .00 & 3 & .15 & 3 \\
\hline Woodward & 422 & .45 & 2 & - & - \\
\hline Maremont & 423 & .50 & 2 & .50 & 2 \\
\hline Warnaco & 424 & .00 & 3 & .00 & 3 \\
\hline KUP Sutherland & 425 & .75 & 1 & - & - \\
\hline Copperweld Steel & 426 & .50 & 2 & .50 & 2 \\
\hline Champion Spark Plug & 427 & .00 & 3 & .00 & 3 \\
\hline American Optical & 428 & .00 & 3 & - & - \\
\hline Needham Packing & 429 & .00 & 3 & .00 & 3 \\
\hline Fibreboard & 430 & .33 & 3 & .33 & 3 \\
\hline Chicago Pneumatic Tool & 431 & .25 & 3 & .25 & 3 \\
\hline Handy and Harman & 432 & .88 & 1 & .88 & 1 \\
\hline Endicott Johnson & 433 & .00 & 3 & .00 & 3 \\
\hline Cabot & 434 & .50 & 2 & .50 & 2 \\
\hline Canada Dry & 435 & .80 & 1 & - & - \\
\hline Wrigley & 436 & 1.00 & 1 & 1.00 & 1 \\
\hline $\begin{array}{l}\text { E. W. Bliss } \\
\text { Crowell Collier and }\end{array}$ & 437 & .50 & 2 & - & - \\
\hline Macmillan & 438 & .00 & 3 & .00 & 3 \\
\hline Bucyrus-Erie & 439 & .50 & 2 & .00 & 2 \\
\hline American Biltrite Rub. & 440 & .50 & 2 & .50 & 2 \\
\hline
\end{tabular}


Appendix B - continued

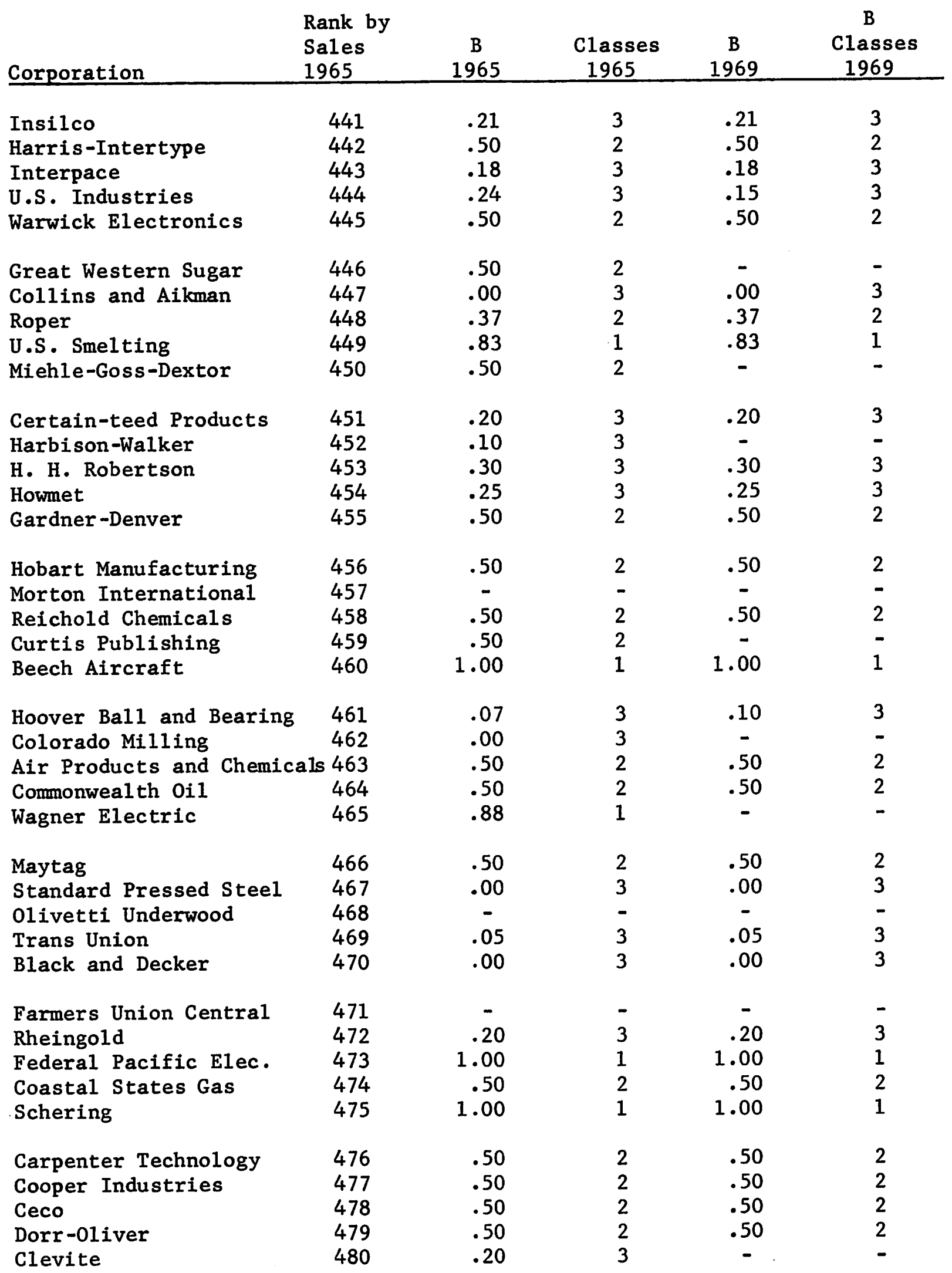


Appendix B - continued

\begin{tabular}{|c|c|c|c|c|c|}
\hline Corporation & $\begin{array}{l}\text { Rank by } \\
\text { Sales } \\
1965 \\
\end{array}$ & $\begin{array}{c}\text { B } \\
1965 \\
\end{array}$ & $\begin{array}{c}\text { Classes } \\
1965\end{array}$ & $\begin{array}{c}\text { B } \\
1969 \\
\end{array}$ & $\begin{array}{c}\text { B } \\
\text { Classes } \\
1969 \\
\end{array}$ \\
\hline $\begin{array}{l}\text { Green Giant } \\
\text { Fairchild Hiller } \\
\text { U.S. Shoe } \\
\text { Warner and Swasey } \\
\text { Brockway Glass }\end{array}$ & $\begin{array}{l}481 \\
482 \\
483 \\
484 \\
485\end{array}$ & $\begin{array}{r}.00 \\
1.00 \\
.00 \\
.50 \\
.00\end{array}$ & $\begin{array}{l}3 \\
1 \\
3 \\
2 \\
3\end{array}$ & $\begin{array}{r}.00 \\
1.00 \\
.00 \\
.50 \\
.00\end{array}$ & $\begin{array}{l}3 \\
1 \\
3 \\
2 \\
3\end{array}$ \\
\hline $\begin{array}{l}\text { Hanes } \\
\text { Northwestern Steel } \\
\quad \text { and Wire } \\
\text { Harnischfeger } \\
\text { Blue Bell } \\
\text { Mead Johnson }\end{array}$ & $\begin{array}{l}487 \\
488 \\
489 \\
490\end{array}$ & $\begin{array}{r}.50 \\
.67 \\
.00 \\
1.00\end{array}$ & $\begin{array}{l}2 \\
1 \\
3 \\
1\end{array}$ & $\begin{array}{l}.50 \\
.67 \\
.00 \\
-\end{array}$ & $\begin{array}{l}2 \\
1 \\
3 \\
-\end{array}$ \\
\hline $\begin{array}{l}\text { Wyandotte Chemicals } \\
\text { Electrolux } \\
\text { Great Northern Nekoosa } \\
\text { Bunker-Ramo } \\
\text { AMP }\end{array}$ & $\begin{array}{l}491 \\
492 \\
493 \\
494 \\
495\end{array}$ & $\begin{array}{l}.50 \\
.00 \\
.25 \\
.50 \\
.50\end{array}$ & $\begin{array}{l}2 \\
3 \\
3 \\
2 \\
2\end{array}$ & $\begin{array}{l}- \\
- \\
.25 \\
.50 \\
.50\end{array}$ & $\begin{array}{l}- \\
- \\
3 \\
2 \\
2\end{array}$ \\
\hline $\begin{array}{l}\text { Pitney-Bowes } \\
\text { Signode } \\
\text { Reeves Brothers } \\
\text { Detroit Steel } \\
\text { Island Creek Coal }\end{array}$ & $\begin{array}{l}496 \\
497 \\
498 \\
499 \\
500\end{array}$ & $\begin{array}{l}.50 \\
.50 \\
.10 \\
.50 \\
.00\end{array}$ & $\begin{array}{l}2 \\
2 \\
3 \\
2 \\
3\end{array}$ & $\begin{array}{l}.50 \\
.50 \\
.10 \\
.50 \\
-\end{array}$ & $\begin{array}{l}2 \\
2 \\
3 \\
2 \\
-\end{array}$ \\
\hline
\end{tabular}

